\title{
5
}

\section{International encounters}

\section{Turkey's relations with Russia}

Past history and present interests combined to transform Turkey's relationship with Russia at the end of the twentieth century into a complex affair fraught with contradiction. The lengthy, intricate, conflict-ridden rivalry between the Ottoman and Russian empires, during the eighteenth and nineteenth centuries, and between the Soviet Union and Turkey, in the twentieth, had left its mark on the relationship between modern-day Turkey and post-communist Russia. The two countries feared yet respected each other. Acknowledging each other's power and recognizing the value of working in tandem, they, at the same time, immensely mistrusted each other, so that all their dealings were marked by extreme caution and wariness. In the 1990s, these ambiguities surfaced as joint Russian-Turkish commercial and military interests vied with bitter regional and economic rivalry. As a result, the two countries' relationship was defined by close, if wary, cooperation, commingled with uncommonly competitive unilateral steps specifically designed to undermine their rival's interests, though again, without ever quite pushing matters to the brink.

\section{Turkey, Russia, and the Central Asian and Caucasus Republics}

Centuries of tension and friction, interleaved with the occasional crisis, had taught Turkey to tread very gingerly where Russia was concerned. Ankara was well aware that the successful pursuit of its regional interests demanded, in the present, as much discretion and circumspection vis-à-vis Russia as it had in the past. This was particularly true in Central Asia and the Caucasus, where, as already noted, Turkey's desire to keep its relations with Russia on an even keel acted as a constant constraint on its policies, and was one of the reasons it 
failed to become the dominant power in the region. Russia, though forced to surrender its Asian empire, following the Soviet Union's disintegration, did not abandon its interest in the area. For one thing, Moscow could not afford to ignore any strategic, economic or even religious developments, in what it termed its "near abroad," that might spill over and have a negative effect on Russia. For another, Moscow still harbored hegemonic ambitions in the region. On both counts the Russians were determined to maintain, and, if possible, extend their influence in both Central Asia and the Caucasus. ${ }^{1}$

Though no longer legally or physically in control of Central Asia and the Caucasus, Russia still made its presence felt throughout the region. Economically, the Republics, in the 1990s were only slightly less dependent on Moscow then they had been in the days of the Soviet Union. The closed and highly centralized economic system, which Moscow had imposed on the Republics and, which had been designed primarily to serve its interests, remained largely intact. For years, the Soviet Union had treated Central Asia and the Caucasus as it's own private and endless source of cheap raw materials and agricultural produce. In order to protect this economic treasure trove, the Soviet Union made sure that other than devoting some resources to the excavation of their natural wealth, the Republics' economies remained almost wholly agricultural. There was very little if any investment in manufacturing, so that the Republics possessed virtually no industrial, and certainly no modern industrial, infrastructures. Thus, for example, while the Republics accounted for 90 percent of the Soviet Union's raw cotton production, 93 percent of the cotton was processed elsewhere. Even in such factories as existed, the technicians, engineers, administrators, and even assembly-line workers were mostly Russians, Ukrainians and Belorussians, the locals, as a rule, being barred from such highly sensitive jobs. The result of all this was, as the Soviets indeed intended, that the Republics, industrially and technologically backward, became totally subservient to Moscow. And, as it was impossible to dismantle such a highly dependent economic system overnight, they remained so well into the 1990s. It was equally unrealistic to expect the Republics to metamorphose instantly from an undeveloped agricultural community to sophisticated industrial one. By the end of the twentith century, the Republics, independent or not, were, much to their chagrin, still reliant economically on Moscow. ${ }^{2}$

It was more or less the same story in the military domain. In the past, Moscow, responsible for the region's security, had provided the Republics with both troops and weapons for their defense. In the 1990s, the Republics, anxious to assert their independence, began to build their own armies. But, with few experienced army personnel and practically no military infrastructures or industry of their own, this proved a formidable challenge. Unable to tackle it successfully on their own, they were forced to turn to Russia for help. They asked for weapons and military equipment, as well as technical assistance, military training, and tactical and strategic instruction. As a rule, officers in the Republics' armies were Russians, not locals. Moreover, with their armies still 
largely in the embryonic stage, the Republics had to rely on the Russian armed forces to defend them, or to deter any significant threat to the region, such as that posed by radical Islamic militants. Russia was quite happy to assist. By sending military advisers, equipment and, when necessary, troops, to the Republics it was able to cement its military hold on the region. In fact, it was even suspected that Russia deliberately fomented unrest in the Caucasus in order maintain troops in the area and guarantee its regional military predominance. ${ }^{3}$

Politically, too, Russia's presence was still felt throughout the Republics. Ever since the 1920s the Soviet Union had kept the Republics on a tight political leash. It sent its own people to the area to ensure that the Republics complied. Taking no chances, it filled the ranks of the Republics' political, economic, administrative, even cultural elite, with Party members. The Republics' declaration of independence, in 1991, produced no equivalent revolution within their ruling establishment. Central Asia's leaders, many of whom were ex-Politburo bosses, were all Soviet-educated, Moscow-orientated men. The Republics' political systems, bureaucracies and academia were still packed with men and women imbued with the old Soviet traditions and practices. While many of these people genuinely wanted to turn their back on the past and their links with Moscow, old ways die hard and the Republics were, in many ways, reminiscent of mini Soviet Unions. There is a hope that, thanks to the growing number of Central Asian students studying abroad and absorbing Western values and democratic practices, the Republics may one day boast a new reformist elite. But, until then, it is the old Soviet guard that rules the roost, often with an iron fist. ${ }^{4}$

Determined to maintain its grip on the Republics and if possible regain its hegemonic position in the region, Russia was prepared to fight off all other contenders to the title. It warned Turkey that any attempt on its part to promote pan-Turkism in Central Asia and the Caucasus or to draw the region into its orbit and away from Moscow's, would be met by a Russian pan-Slavic offensive in the Christian Orthodox areas of the Balkans and Central Asian. It was a powerful threat, which Turkey could ill afford to ignore, unless, of course, it wanted to find itself embroiled in an ethnic and religious Turkic-Slavic struggle, which it most certainly did not. It had no desire to raise against it or against any of its fellow ethnic communities the wrath of the entire Christian Orthodox world. The last thing Ankara wanted was to see the Turkish and Turkic minorities in the Balkans and Central Asia, who were often discriminated against anyway, fall victim to even greater persecution. Aware of the ethnic powder keg these regions constituted, it had little stomach for the resumption of the vicious racial-religious wars, which had devastated whole communities, with Serb set against Bosnian and Albanian against Serb. If Turkey had any doubts, which it did not, that Russia meant what it said, it only had to look to Bulgaria's brutally discriminatory policies vis-à-vis its 1.5 million strong Turkish minority and Russia's and Armenia's ruthless suppression of their respective Chechen and Azeri minorities. With both countries enjoying close links with Russia, Ankara 
was convinced that their actions were a sign of things to come if it insisted on playing the pan-Turkic card, contrary to Moscow's warnings.

Pursuing the Pan-Turkic theme, Moscow hinted that any bid on Turkey's part to encourage the Russian Federation's Muslim Turkic minorities to secede, would be countered by a Russian endorsement of the secessionist efforts of Turkey's minorities, the Kurds in particular. With Moscow's backing, Turkey's minorities stood a good chance of making Ankara's life even more difficult than it already was, or, worse, succeeding in their endeavors. ${ }^{5}$ Clearly, Turkey could not brush aside this barefaced threat to it territorial integrity. Add to this, Russia's extensive military presence along the Armenian-Turkish and GeorgianTurkish borders and it is easy to see why Turkey was very careful not to do in anything that might excite Russian suspicions. In 1999-2000, despite having saluted the Chechens' efforts to shake off the yoke of Russia's "cruel colonial imperialism," which, it emphasized bore absolutely no resemblance to the "terror motivated" Kurdish insurrection, Turkey failed to intervene in the Chechen war of independence. ${ }^{6}$ Much to the exasperation of its own Turkic ethnic lobbies, Ankara, insisting that the matter was an internal Russian affair, did nothing to stop Moscow brutally reasserting its control over Chechnya. Moreover, anxious not to provoke Moscow unduly, it pointedly ignored the devastation and mass carnage Moscow spread in the course of the fighting, its sole reference to the matter being to lament the terrible humanitarian tragedy caused by war in general. In like manner, in fear that Russia might draw a parallel between the Kosovar's Muslim Albanians' national rights and those of Turkey's own minorities, thus stirring up the Kurds and Armenians in Asia Minor, Ankara did not back the Kosovar's Albanians' efforts to secede from Serbia, another Russian regional protégé.

\section{Energy resources: gas and oil}

Questions of fuel and energy featured at the top of both Russia's and Turkey's agenda. Their relationship in this respect, combining the Turkey's lack of sufficient oil and gas resources, Russia's frantic need for money, as well as the desire of both to monopolize Central Asia's and the Caucasus' energy market, was a typical example of how the two countries often veered from close cooperation to fierce competition. Throughout the 1990s, Turkey imported most of its gas from Russia who, with 49 trillion cubic meters of gas, possessed the largest gas reserves in the world. In 1997, having decided to reduce its dependence on oil, Turkey signed an agreement with Russia for the purchase of 16 billion cubic meters of gas a year. This was meant to cover 50 percent of Turkey's estimated gas needs, as well as help it overcome any possible future gas shortages. With demand for gas set to rise from 12 billion cubic meters, in 1999, to 42 billion cubic meters, in 2005, Turkey faced the prospect of severe gas shortages and needed all the gas as it could get. 
It was no coincidence that the Russian gas agreement was signed more or less at the same time as the EU, once again, rejected Turkey's membership application. Aggrieved and alienated by Europe's decision, Ankara pointedly set about improving its relations with Russia. But, despite its many advantages, the Russian gas deal also possessed several significant drawbacks. First, it was dependent on the execution of an immensely ambitious and complicated engineering project. The agreement, known as "Operation Blue Stream" involved two stages. During the first stage, the existing gas pipeline between Russia and Turkey was to be expanded to double its current capacity. During the second stage, a $1213 \mathrm{~km}$ long, 2100 meter deep pipe - the deepest in the world - was to be laid under the Black Sea, carrying Siberian gas to Turkey's Black Sea port of Samson and from there to Ankara. The pipeline, to be built by an international consortium of French, Italian, Japanese and Russian energy companies, at the cost of 3.2 billion dollars, was to be completed by 2010. . Small wonder its opponents ridiculed the entire scheme, labeling it derisively, "Operation Blue Dream." Second, while reducing Turkey reliance on oil, it increased Turkey's dependence on Russian gas. Turkey already imported 68 percent of its gas from Russia. In 1999 it was importing 7 billion cubic meters of gas from Russia as compared to only 5 billion from Algeria and Nigeria, its other two primary gas sources. This was far too much. Not wanting to become totally dependent on Moscow, which in light of the various areas of conflict between them, was simply too dangerous, Turkey began looking for other gas suppliers. Hence the 1996 Iranian-Turkish gas deal, followed by the 1999 Turkameni gas agreement. Turkey also decided to diversify its energy resources, buying more electricity from its immediate neighbors. However, Blue Stream threatened to rival and undercut Turkey's other regional energy projects, such as the Turkameni gas deal, with Turkey having to choose between financing Operation Blue Stream or the Turkameni gas project, a hard choice given the advantages of both. ${ }^{8}$ Blue Stream also presented a potential challenge to the Baku-Tiblisi-Ceyhan pipeline, about which more later.

There were few things that Turkey would have liked more than to end Russia's monopoly over Central Asia's and the Caucasus' fuel market. Once they were able to extract and transport their gas and oil resources without Russia's help, the Republics would not only become more independent economically, and therefore politically, but also better equipped to fulfill one of their primary functions, as Turkey sees it, and form a buffer zone between it and Russia. ${ }^{9}$ Better still they would be free to draw closer to Turkey. Abolishing the Russian fuel monopoly would also, and no less importantly, allow Turkey to exploit the Republics' energy resources itself. In the 1990s, Turkey, as noted, needed all the oil and gas it could get, and, given that it was determined not to become dependent on a single supplier, from as many sources as possible. The fuel-rich Republics offered a solution to both problems. They were also a potential money-spinner and could provide Turkey, if it played its cards right, with a handsome source of income. Hence, Ankara encouraged the Republics to 
embark upon various energy projects independently of Russia, ideally in cooperation with Turkey itself. The only problem was Russia, who seeing things differently, was determined to maintain its hold on the Republics' fuel market, and who, with a head start in the regional energy game, could and did spoil many a Turkey-inspired deal.

In 2000, Russia and Turkmenistan closed a deal allowing Russia to buy 40 billion cubic meters of gas a year from Turkmenistan. The agreement, immediately set alarm bells ringing in Ankara. For one thing, it entrenched Russia's presence in the region. For another, it posed a threat to Turkey's own arrangements with Turkmenistan, in that there was the distinct possibility, or so Turkey feared, that there would not be enough gas left over for Turkey to transport to Europe, as posited in the Turkmeni-Turkish agreement. Turkey had no doubt that this was precisely Russia's intention. Hoping to corner the European gas market itself, and aware that "the next stage of our Turkmeni gas project is the sale to Europe," Russia, Cumhur Esumer, Turkey's Energy and Natural Resources Minister protested, "is trying to block us."

But two could play at that game. In 1997, Turkey set in motion a plan to build a pipeline to transport Azeri oil through Georgia to the Turkish Mediterranean port of Ceyhan and hence to Europe, by passing Russia altogether. In an effort to promote the project, known as the Baku-Tiblisi-Ceyhan route, Turkey boasted that the Ceyhan port's loading facilities were vastly superior to those of the Russian port of Novorossiysk, which until now had a virtual monopoly over the transport of Central Asian oil to Europe. It also made public Russia's habit of diluting high-grade Azerbaijani light oil with inferior, sulphurous Russian crude. Turkey, on the other hand, could guarantee to supply Europe with prime unadulterated Azeri oil. One of the Baku-Tiblisi-Ceyhan route's many advantages was that, once operational, it would end Russia's monopoly over the transport of Central Asian oil. Another was that it would reduce maritime traffic, in the hugely congested Straits. ${ }^{11}$

\section{The Straits}

The $28 \mathrm{~km}$ long Bosporus Strait (Strait of Istanbul) and $70 \mathrm{~km}$ long Dardanelles Strait (Strait of Canakkale) linked by the Sea of Marmara, is one of the busiest waterways in the world. Three times more ships pass through the Bosporus each year than though the Suez Canal and four times more than through the Panama Canal. Traffic in the Straits even outstrips traffic in the Straits of Hormuz, commonly held to be the most crowded in the world. In 1996, a total of 49,952 and 36,198 vessels sailed through the Bosporus and the Dardanelles, respectively. In 1997, some 50,000 ships traversed the Straits, including sixty warships, 4,500 oil tankers, and a large number of merchant ships and leisure cruisers. This is in addition to the 1,500 intercity ferries and shuttles which sail back and forth between the eastern and western sides of Istanbul each day, carrying some of the 
500,000 people who cross the city, either by bridge or boat. Then there are the vast number of fishing boats, which ply their trade across the Sea of Marmara. Unfortunately for Turkey, far from being static, these numbers grew by leaps and bounds. Since 1960, the total number of foreign vessels passing through the Straits has increased by 150 percent, their tonnage by 400 percent. ${ }^{12}$ During the 1990s, traffic in the Straits grew at an alarming rate of 15 to 20 percent per annum, so that by the early 2000s the number of ferries crossing the Sea of Marmara is expected to reach an impossible 2,000 a day. ${ }^{13}$

Oil tankers account for a large percentage of the Straits' traffic. In 1996 alone, 4,248 oil tankers passed through the Bosporus and 5,657 through the Dardanelles. Ten to fifteen supertankers, one or two of them exceeding 210 meters in length, cross the 700 yards wide Straits daily, carrying on board a variety of extremely hazardous substances, including crude oil, liquid gas chemicals, pesticides and herbicides. These ships are so big and their cargo so dangerous that Turkey is forced to close waterway to all other ships, until they complete their two-hour long journey through the Straits. The result is a huge backlog and even bigger bottlenecks than usual. With the number of big tankers expected to rise, Turkish officials have warned that the Bosporus would eventually have to be closed four times a day, creating even greater delays and worse congestion. ${ }^{14}$

The Bosporus and Dardanelles are not only the busiest straits in the world, they are also among the most difficult to navigate. Crossing the labyrinth-like Bosporus is a highly skilled and chancy business. Full of twists and turns, ships are forced to change course at least twelve times, four times at an angle greater than 45 degrees, as they wend their way though the waterway. To make matters worse, the Bosporus possess few shallows or sandbars, upon which ships in trouble can ground themselves before smashing into the shore. As a result, more than one ship, having lost its bearings, found itself crashing into houses built along the strait's shore, leading to sardonic comments about "the limits of Turkish hospitaliy." ${ }^{15}$ The Dardanelles, which boasts six sharp turns, some requiring ships to alter their course abruptly at an 80 degree angle, are no better. At two points, Kandilli and Yenikoy, the ships' navigators, unable to see either the ship's port or starboard side, are forced to steer by a combination of skill and blind luck. Add to this the fact that the entire waterway suffers from bad weather, fog and unpredictable currents, and navigational risks increase tenfold. For example, if in normal times, the north to south current from the Black Sea to the Sea of Marmara, is something between 3 to 4 knots, in rough weather it increases to a frightening 6 to 7 knots. As if that was not enough, the Straits also incline at a 20 degree angle north to south, which combined with the fairly rapid currents, transform any journey down the Straits into something reminiscent of a luge. ${ }^{16}$

The combination of heavy traffic, the difficulties of maneuvring through the Straits, and the often dangerous cargo on board many of the ships, is an explosive one. Between 1983 and 1993, there were 167 large-scale accidents in the Straits, all with appalling physical and environmental consequences. During the 1990s, over 150 accidents took place in the Straits. In 1992, a Lebanese vessel 
carrying 13,000 sheep and goats went down in the Bosporus. Old, decrepit and uninsured, the ship was not considered worth salvaging, and was left, together with its cargo, to rot on the bottom of the sea. Accidents involving oil tankers have proven particularly nasty. In 1997, the oil tanker Nassia, carrying 19 million gallons of oil went up in flames and began drifting perilously close to the Bosporus's European shore. It took the Turkish authorities seven days before they managed to tow the burning wreck out into the Black Sea and so avoid a colossal disaster. As it was, maritime traffic in the Straits was interrupted for an entire week, causing huge delays and thus increasing the odds on further accidents happening. In the midst of all this, the Turkish Daily News suggested, sarcastically, that someone should "try that in the middle of New York City or any major American or European port city." 17

Nor was that the end of it. In December 1997, a Norwegian tanker heading towards Western Europe, with 30,000 tons of Russian crude on board, narrowly missed one of the Bosporus's twin bridges. In August 1998, a Greek tanker carrying 87,000 tons of crude oil ran aground, forcing the Turkish authorities, yet again, to close the Straits. In October that year, a Turkish oil tanker collided with a water tanker. Luckily, in all these cases the oil in the ships' hold did not spill overboard..$^{18}$ Even more fortunately, no supertankers have, so far, been involved in a fatal accident in the Straits. The devastation caused by a supertanker explosion would equal that produced by an earthquake measuring 11 on the Richter scale. It would also set off a succession of maritime accidents in the Straits, wreaking unspeakable havoc on the densely populated shores of the Sea of Marmara, and utterly destroying the Straits ecosystems..$^{19}$ But, it did not take an accident to ravage the Straits' marine ecology. Heavy traffic and the increasing amounts of human and industrial waste pouring into the Straits have terminally damaged much of the waterway's plant and animal life. According to environmentalists, for example, out of the 160 fish species indigenous to the Straits only twenty-six still survive. ${ }^{20}$

The discovery, in the 1990s, of oil in the Caspian basin meant, or so Turkey feared, that the situation in the Straits would go from bad to worse. By the end of the 1990s, oil tanker traffic from the Black Sea port of Novorossiysk to the Straits had doubled in number. Add to that the transport of another estimated 80 or 100 million tons of Caspian oil a year and, by 2010, the number of ships passing through the Straits would triple, or more. With the odds on the Straits' marine life suffering irreversible damage or some catastrophic accident taking place rising daily, Turkey, insisting that the Straits have only finite shipping capacity, took steps to monitor and reduce traffic in the waterway. To this end, it unilaterally modified the 1936 Montreux Straits Convention, which until then had regulated shipping through the Straits. Under the Convention, Turkey had no right to impose restrictions on vessels using the Straits. It could not, as is the case in the Panama Canal, require ships, regardless of whether they were small boats or supertankers, carrying dangerous cargo or not, hire specially trained pilots to steer them through the Straits. As a result, only 40 percent of all large 
ships navigating the Straits bothered with the expense of hiring skilled pilots. Unfortunately, these were usually the ships in the worst condition, and, which, if they ran aground, would cause the greatest amount of damage. Yet, despite the fact that most of the serious accidents in the Straits involved ships without pilots, under the Convention there was nothing Turkey could do. It could not even reduce the risks by ordering ships to install basic safety features, such as a double hull. Nor could it oblige them to carry insurance, which would at least cover the cost of any damage they caused. Worse, still, given that passage through the Straits was toll free, it fell to Turkey to pay for any damage done as well as to pay for the upkeep of the Straits. ${ }^{21}$

It was an intolerable situation, which, in light of current maritime trends, would only deteriorate further. Arguing that shipping conditions had changed radically since in 1936 rendering the signing of the Montreux Convention obsolete - for example, whereas in 1936 approximately two ships crossed the Straits each day, by 1990s an average of 134 ships passed through the Straits daily; similarly, in 1936 the average oil tanker measured 40 meters, but by the late 1990s a typical oil tanker was 350 meters long; and in 1936 Istanbul's population was 1 million, but by the end of the twentieth century it was 12 million, all of which meant that the odds on an accident happening were far greater and its consequences far graver $^{22}$ - Turkey began unilaterally to revise the rules regulating traffic through the Straits. In June 1994, it introduced the Bosporus and Canakkale Safety of Passage Act, which imposed various restrictions on ships sailing through the Straits, especially those carrying oil and other flammable materials. According to the Act and its various subsequent amendments, all vessels passing through the Straits must be fully insured. Ships over 300 meters long could enter the Straits only after they had received the Turkish maritime authorities' permission. No ship above 190 feet in height was allowed to cross the Straits as there was every chance that they would crash into one of the two suspension bridges spanning the Bosporus, north of Istanbul. These new rules restricted oil supertanker traffic in the Straits. But, even ordinary oil tankers were affected by the new regulations. Henceforth only double-hulled tankers, of whatever length, would be allowed across the Straits. All dangerous cargo must be declared and Turkey reserved the right to conduct spot checks, as well as to inspect the ships' safety facilities. The number of tankers and quantity of oil crossing the Straits at any one time was, henceforth, severely restricted. Oil tankers were not allowed to queue-jump any more. All ships were limited to a speed of 10 knots and overtaking was absolutely forbidden. Finally, Turkey had the right to close the Straits, during fire-fighting and rescue operations, during anti-pollution operations, when taking soundings, while carrying out scientific research, and even during sporting events. ${ }^{23}$

Still not satisfied, Turkey periodically imposed new restrictions on shipping passing through the Straits. It also installed several new and very expensive traffic management systems in the waterway. The cost of building and running these systems, and any other schemes Turkey might come up with in the future, 
was to be born by the ships themselves, which would, henceforth have to pay a special levy to cross the Straits, a particularly high one in the case of oil tankers ferrying oil from the Russian port of Novorossiysk to Europe. Not surprisingly, the majority of Straits users strongly objected to the new regime. Foremost among the protesters was Russia, who was particularly hard hit by Turkey's unilateral actions. Russian trade relied heavily on the Straits and almost a third of the ships crossing the Straits flew the Russian flag. Tightening the rules of passage and forcing Russia to pay for the privilege of crossing the Straits as well, meant fewer ships, less trade and a significantly smaller income. It would also discourage foreign entrepreneurs from investing in Russia, thus reducing even further the country's chances of economic recovery.

Russia suspected that Turkey deliberately sought to reduce, if not completely stymie Russian shipping through the Straits in order to increase the odds on the materialization of its Baku-Tiblisi-Ceyhan scheme. It claimed that Turkey's environmental concerns were entirely feigned, and like its constant harping on the dangers arising from the growing number of ships navigating the Straits - according to Russia there is no limit on the number of ships that can safely cross the Straits at any one time - was meant simply to promote the Baku-Tiblisi-Ceyhan pipeline, at Russia's expense. Russia also, and somewhat contradictorily, while insisting that the Straits Act was totally unnecessary, accused Turkey of failing to improve safety standards in the Straits in the hope that future accidents will put yet another obstacle in the way of the Novorossiysk route. But, with the profits on the transport of 80-100 millions tons of oil at stake, Russia, not surprisingly, felt that it had to muster every argument it could, contradictory or not. Nor were Russia's accusations entirely spurious. While Turkey's environmental and other concerns were very real, the bonus effect of the Straits Act in terms of promoting the Baku-Tiblisi-Ceyhan route did not escape Ankara's eye. There is little doubt that as far as Turkey was concerned, the new Straits regime served the dual purpose, of, on the one hand, making the Straits a safer place, and, on the other, advancing Turkey's fuel policies. As for the latter it remains to be seen whether the new shipping restrictions in the Straits will indeed advance the Baku-Tiblisi-Ceyhan project at Russia's cost.

\section{Common interests: civil and military trade}

In as much as Turkey would have liked to have undercut, even expropriate, Russia's monopoly over Central Asia's and the Caucasus' oil, it could not afford - even for such high stakes - to alienate Russia completely by pushing matters too far. Not only was Russia too big and too dangerous to provoke, and Turkey loath to endanger its supply of Russian gas, but there were also several other important military and economic interests at stake. Throughout the 1990s, Turkey and Russia enjoyed an extremely profitable commercial relationship, which, to a degree, tempered their political and strategic rivalry. Turkish trade 
with Moscow had flourished during the 1990s, and, though, by 1999, Russia was no longer the commercial gold mine it had been, owing to the demise of the lucrative suitcase economy, the CIS still accounted for 9 percent of Turkey's overall imports - well ahead of the United States and the Middle East - and 5.6 percent of its exports. ${ }^{24}$ This was not something Turkey would give up lightly. Nor was it all a one-way street. As Russia's principal trading partner in the Middle East, Turkey helped shore up Russia's faltering economy and Russia had every reason to try and expand its commercial links with Ankara even further. Accordingly, throughout the 1990s, Turkey and Russia signed many trade deals and were continuously negotiating new ones. Their aim was that by 2010 bilateral trade between them should reach the sum of 10 to 12 billion dollars a year, making Turkey one of Russia's biggest trading partners, second only to Germany, currently Moscow's chief trading partner. It was an attractive prospect and provided both countries with a strong financial incentive to keep their relations on an even keel..$^{25}$

In 1993, Russian-Turkish trade took on a new dimension, as Ankara began to purchase weapons from Moscow. The West's reluctance to sell Turkey arms for fear that they might be used against the Kurds and its, to Turkey, irritating habit of threatening to deny Turkey weapons in order to, as Ankara sees it, blackmail it into improving its human rights performance, forced the Turks to look for other more reliable, less fastidious arms suppliers. Russia was the obvious choice, and Turkey in urgent need of arms, had few qualms in buying them from NATO's principal ex-enemy. Moscow, in turn, desperate for money, was only happy to oblige. Thus, Turkey became the first NATO country to purchase, on a regular basis, a wide range of Russian military equipment including helicopters, armored personnel carriers, and air defense systems. It, naturally, did not want to do anything to jeopardize this welcome and relatively secure source of weapons. ${ }^{26}$

While Turkey's relationship with Russia, during the 1990s was often distinguished by rivalry, especially in Central Asia, open conflict with Moscow was never an option. For one thing, Turkey's basic westward orientation meant that it was simply not worth its while to contest Russia's bid for the mastery of Central Asia and the Caucasus. Especially not in view of Russia's determination to retain its hold over its former Asian empire and its ability severely to bruise Turkey, if not worse, should Ankara be foolish enough to push Moscow to the brink. ${ }^{27}$ For another, Turkey had too many other more pressing problems and conflicts to deal with. What with Syria, Iraq and Iran to the east and Greece to the west, Turkey had quite enough on its hands as it was, and had no need to make its life even more complicated by adding Russia to its list of enemies. Admittedly, some of these conflicts were quiescent, while others were in the process of being resolved in Turkey's favor, still it would have been, as Ankara well knew, foolhardy of it deliberately to go looking for trouble, especially with Russia. The Turkish tradition of avoiding, where possible, unnecessary conflicts also helped temper Ankara's policies towards Russia. It was for a combination of these reasons that Turkey refused to act as the local representative of Western 
interests in Central Asia. If the West, and especially the United States, wanted to restrict Russia's political or economic hegemony in the region, then, Turkey believed, it should do something about it itself and not expect Turkey to fight its battle for it. Again, for Turkey, who looks westwards, it seems pointless to struggle with the Russians over mastery in Central Asia.

\section{A new cold war: the battle for Central Asia's energy resources}

Central Asia and the Caucasus' huge oil and natural gas reserves are an immensely valuable economic prize, well worth fighting over. The known Caspian Sea oil reserves, some 15 to 29 billion barrels, are equal to those of the North Sea. Early soundings, however, indicated that the real amount was much greater, perhaps as much as 163-200 billion barrels of oil, which was roughly a quarter of the Middle East's oil reserves. The region's gas reserves stood at 10 trillion cubic meters, or 12 percent of the world's gas reserves, and were equal to 160 billion barrels of oil. ${ }^{28}$ Small wonder that during the 1990s this gargantuan well of fuel was the subject of intense international competition. Turkey, one of the participants in the battle over the regions' energy resources, became one of the key players in the Central Asian fuel market. With its ever-growing energy needs, Turkey required the region's oil and gas for its own consumption. In order to jump the queue and convince the Republics to sell their fuel to Turkey first, Ismail Cem called their attention to the fact that not only did Turkey require and would continue to require vast amounts of oil and gas in the future, but that it was "the only country that can pay cash, pay it now and continue to pay it up front." ${ }^{29}$ By posing as a dependable, highly profitable and long-term customer, Turkey was able to obtain a 49 percent interest in an international consortium that had the right to explore Aktau in Kazakhstan's gas reserves. Turkey also hoped to make some money by transporting and distributing Caspian oil to Europe by means of the Baku-Tiblisi-Ceyhan pipeline. The pipeline would also, as noted, relieve traffic congestion in the Straits, by offering an alternative to the Novorossiysk route; congestion, which, Turkey feared would only get worse once Russia's mega-tankers began to transport Caspian oil as well. In order to promote the project Turkey capitalized on the fact that, situated halfway between East and West, it was, as it pointed out to all concerned, the ideal distribution point for Central Asian oil and gas. ${ }^{30}$

While Russia, which wanted to exploit the region's oil and gas resources itself, might contest Turkey's claims and try to frustrate its plans, the United States chose to ally itself with Turkey in the battle over the region's energy resources. During the 1990s, with its own oil reserves dwindling daily, the United States became increasingly dependent on oil imports, and oil from Venezuela, Mexico and the Persian Gulf soon accounted for 50 percent of American oil consumption. By 2010, this figure is expected to rise to 60 percent. ${ }^{31}$ The United States, having learnt the lessons of the 1970s oil crisis well, was determined that 
its "economy will never again be held hostage" to a single oil supplier. Accordingly like Turkey, it sought to diversify its fuel suppliers. Likewise, and for much the same reasons, it hoped to establish multiple routes for the transport of oil, so that Iran, for example, could not blackmail the United States by blocking or threatening to block American oil supplies..$^{32}$ But, as a global superpower, the United States also looked beyond its specific energy requirements. With global oil consumption expected to grow by an average of 2 percent a year, by 2015 the world's energy consumption, standing at 104 million barrels a day, would be 55 percent higher than it was in $1995 .{ }^{33}$ Not wishing to deplete the world's existing resources, or give any current oil producer too much economic and political power, the United States encouraged the advent of as many new alternative energy providers as it could. The addition of "new players," would also, the United States believed, "make energy markets more competitive, transparent and market sensitive, three perquisites of an efficient and smoothly functioning world energy sector." In other words it would keep fuel prices low. This was certainly true of Caspian crude, which cost only 5 dollars per barrel to produce, more than Saudi Arabia's rock bottom operating costs of 1.5 dollars per barrel, but less than the North Seas 13 dollars. ${ }^{34}$ Inevitably perhaps, plain profit also played its part in exciting the United States' interest in Caspian oil, with American oil companies hoping to obtain a large chunk of the highly lucrative Caspian Basin oil business. ${ }^{35}$

\section{The Azerbaijan International Operating Company "Contract of the Century"}

Azerbaijan was lucky enough to own a significant proportion of the Caspian basin's oil reserves. In 1997, Azerbaijan's known oil reserves were 17 billion barrels, or 0.7 percent of the world's known reserves. By 1998, this rose to 27 million barrels. ${ }^{36}$ By the end of the century, with its oil reserves thought to rival those of Kuwait, Azerbaijan was set to become the world's largest oil producer and exporter. Turkey, who enjoyed a close relationship with Azerbaijan, was quick to get in on the act, obtaining a 9 percent stake in an international consortium that had secured the rights to the Shah-Deniz oil field. ${ }^{37}$ But, Turkey's greatest coup was to acquire a 6.75 percent share in the Azerbaijan International Operating Company (AIOC), established in September 1994. The AIOC brought together the Azerbaijani government, on the one hand, and an international consortium of public and private oil companies headed by the United States, on the other. ${ }^{38}$ The AIOC agreement, "Contract of the Century," ${ }^{39}$ led to establishment of an operating company which owned the drilling rights to Azerbaijan's three major oil fields, Azeri, Shiraq and Gunsheli, from which it was eventually hoped to extract some 3.9 million barrels of oil or 35-40 million tons of oil, a year. More realistic estimates set production levels at 800,000 barrels a day, which, at an outlay of a mere 5 dollars per barrel, would still be enough to 
provide AIOC members with a tidy profit. The AIOC operating company was also to finance the construction of a pipeline to transport the Azeri oil to outside markets. Turkey, naturally, hoped that the AIOC would select the port of Ceyhan as the pipeline's termination point and to its immense delight it discovered that in this it had the full support of the United States. ${ }^{40}$

\section{Energy routes: the Baku-Tiblisi-Ceyhan pipeline}

The United States, in line with its goal of increasing the number of global fuel transportation routes across the globe, envisioned the creation of an East to West Caspian energy corridor. In practise, the corridor would consist of twin oil and gas pipelines, which, running under the Caspian Sea, would link Kazakhstan and Turkmenistan, on the sea's eastern shore, with Azerbaijan, to the west. From Baku the two pipelines would continue westwards crossing Georgia into Turkey and finally emerging in the Turkish Mediterranean port of Ceyhan. The oil pipeline - some $1728 \mathrm{~km}$ long - was, once operational, hopefully by 2004, to convey 25 million tons of Azeri crude plus 20 million tons of Kazakh crude, a year. It was an immensely complicated and expensive engineering project. The Republics had neither the technical knowhow nor the money - an initial estimate of 2.4 billion dollars soon swelled to a massive 3-4 billion dollars needed to build the pipelines themselves. Oil revenue money went some way toward paying for the project, as did Turkey's commitment to buy gas from the Republics, which the latter used as collateral to obtain funds for the pipelines' construction. But this provided only a drop in the ocean as far the money needed to finance the project went. Turkey had too many economic problems of its own to afford to go it alone, however much it would have liked to. Clearly, the project was in urgent need of outside investors. Luckily, there was the possibility that the United States, who expressed a great deal of interest in the pipeline, might bail out the project. For one thing, it fell in line with the United States' global energy policies. For another, by passing Russia and Iran, hitherto the region's traditional fuel transport routes, the pipeline dovetailed with the United States' strategic interests. It would help weaken, and possibly isolate, Iran. It would also end Russia's monopoly over the transport of Central Asia's energy resources, thus significantly reducing the Republics' dependence on Moscow. Finally, championing the Baku-Tiblisi-Ceyhan route was also, the Americans thought, a way of compensating Turkey for the economic hardships it had endured in the wake of the Gulf War. ${ }^{41}$

Azerbaijan was keen to cooperate. Eager to reduce its dependence on Russia, its arch-rival Armenia's patron, Baku pushed hard for the southern Ceyhan route. The Baku-Tiblisi-Ceyhan project would also, the Azeris hoped, as a bonus, result in the annulment of section 907 of the United States' 1992 Freedom Support Act (FSA). Thanks to the FSA, which sought to help the ex-Soviet Republics find their economic, social and political feet, the United States poured some 1.3 billion 
dollars into Central Asia and the Caucasus between 1992 and 1998. Medical care, particularly prenatal and child healthcare was a top priority, and the United States spent vast amounts of money modernizing the Republics' primitive health infrastructures. It sent them medicine and basic medical equipment, as well as doctors and medical teams to help combat various infectious diseases such as tuberculosis, which still plagued the region. The United States also became one of chief contributors to the United Nation's High Commissioner of Refugees' program to relieve the plight of the hundreds of thousands of refugees in the region. It even sent, on its own initiative, 200,000 ready-made meals to help feed some of these unfortunate people. Azerbaijan, to its intense disappointment, benefited very little from all this. In 1993, following the Nagorno-Karabakh war and some very heavy pressure on the part of the American Armenian lobby, the Senate passed an amendment to the FSA, known as section 907, which severely limited the amount of humanitarian assistance Azerbaijan could receive directly from the United States. Other than protest, there was very little Azerbaijan could do about this, until, that is, the discovery of Azeri oil, which together with the southern pipeline route constituted a powerful incentive for the United States to abandon section 907, not least because Washington feared that if it did not clinch the deal, others such as the EU, Japan, or even Iran, would. Azerbaijan, thus had every reason to hope for the best, as did Turkey. ${ }^{42}$

Turkey had great many hopes invested in the Baku-Tiblisi-Ceyhan route and launched a public relations campaign highlighting the project's many advantages. Russia, it pointed out, owing to stormy weather, was regularly obliged to close its Black Sea ports for part of the year. The Ceyhan port, on the other hand, which enjoyed a mild Mediterranean climate, could operate all year round. When discussing the route's many merits, Ankara tended to emphasize those that just happened to mesh with the United States' interests. It called attention to the fact that the three current fuel routes ran though Russia, Armenia and Iran, all of which were either politically unstable or hostile to Washington. This could not be said of Azerbaijan, Georgia or Turkey. The project would also, Ankara enthused, end Russia's monopoly over the Republics' oil exports and thus loosen its grip on the region. ${ }^{43}$

The Baku-Tbilisi-Ceyhan project faced several problems, most of which involved money. The Republics' oil industries were in their infancy and few of them had the infrastructures necessary to carry out oil exploration operations, to drill for oil or to transport it elsewhere. In most cases these had to be built from scratch - a costly business, which might prove too much for investors, especially if there were other less expensive alternatives, such as, for example, the Middle East, available. Indeed, the landlocked Republics, with their nascent oil industries, found it very difficult to compete with the Middle East which, thanks to its flourishing seventy-year-old oil business and easy access to the sea, could afford to sell its oil at rock bottom prices and keep transport costs to a minimum. As for transporting Caspian oil itself, Iran, Armenia and Russia all offered cheaper and quicker alternatives than the Baku-Tiblisi-Ceyhan route. 
Azerbaijan's reluctance to send its oil across Armenia, and Turkey's and the United States' veto on the idea of ferrying the oil through Russian or Iranian territory, left Georgia, as the only possible land link, and a much longer one at that, between Azerbaijan and Turkey. Pumping oil through pipelines is an expensive business - the longer the pipeline the higher the outlay - and, at $1728 \mathrm{~km}$, the operating costs of the Baku-Tbilisi-Ceyhan line were daunting. A highly circuitous route, it would also take much longer to transport the oil. Conversely, Russia’s Baku-Novorossiysk and Georgia's Baku-Suspa - Suspa being Georgia's Black Sea port - routes were shorter, cheaper and, no less importantly, already being used to ship small amounts of Azeri oil across the Black Sea. Accordingly, with their infrastructures more or less in place, they could be ready to ferry large amounts of oil far sooner than the Baku-Tbilisi-Ceyhan pipeline, and at a fraction of the cost. The Caspian Pipeline Consortium's pipeline (CPC) was another more cost effective alternative to the Baku-Tiblisi-Ceyhan route. The $1580 \mathrm{~km}$ long pipeline - costing 2.5 billion dollars - was to connect the Tengiz field's oil in Kazakhstan to Russia's Black Sea port of Novorossiysk. Boasting a capacity of 560,000 barrels per day, or 28 million tons a year, it had every chance of becoming the principal transport route of Caspian crude over the next twenty-five years. The CPC had one other huge advantage over its rival: it was run by the powerful American Exxon and European Chevron oil companies, and was thus likely to win Western backing In sum, given the estimated cost of the BakuTiblisi-Ceyhan route which at 3-4 billion dollars, was twice, even three times, more than that of any of the rival routes, there was every chance that the AIOC would eventually opt for one of the already functioning, shorter or cheaper Black Sea routes. ${ }^{44}$

Global oil prices also reduced the odds on the Baku-Tiblisi-Ceyhan project ever seeing the light of day. In the late 1990s, overproduction led to huge oil surpluses and, as a result, a massive drop in oil prices. The Caspian states, as newcomers to the oil business, had, at first, to make do with even lower prices. This jeopardized the Baku-Tiblisi-Ceyhan project on two counts: first, because the construction of the pipeline was to be financed in part with oil revenue money; second, because the AIOC companies may balk at the idea of building an expensive pipeline, expensive to build and expensive to run, in return for a profit so small it would hardly cover their outlay. One way around the problem was simply to ship more oil in return for more money. Indeed, it was generally agreed that in order to become economically viable, the pipeline had to convey oil from Turkmenistan and Kazakhstan - potentially the Caspian Sea's two largest oil producers - as well from oil fields still under exploration. Yet, even this additional oil may not be sufficient to turn the pipeline into a financially sound venture. Though by 2008 , the region will probably produce some 700,000 barrels a day, this will still not be enough to offset the pipeline's operating costs, not to mention a decent profit margin for investors. ${ }^{45}$

But perhaps the greatest obstacle to the Baku-Tiblisi-Ceyhan pipeline's prospects was Russia's fierce opposition to the project. Russia was convinced 
that the pipeline was part of a long-term American-Turkish plot - conspiracy was how it put it - to undermine Moscow's position in Central Asia and the Caucasus, and take over the region's oil market. While Russia was confident that it could handle Turkey fairly easily, having already had some experience in successfully fending off Turkish challenges in the region, Washington's intervention was a completely different story. Though the United States' growing interest in Central Asia and refusal to recognize it as a Russian sphere of influence came as no surprise, it did, nonetheless cause concern in Moscow. The Russians interpreted the United States' constant meddling in the Republics as part of an overall program designed to drive Russia out of the Central Asia and the Caucasus region and replaced it as the dominant regional power. In order to verify their theory the Russians only had to look to the part the Americans played in the establishment of the Central Asian Peacekeeping Battalion (CENTRASBAT). CENTRASBAT was set up in order to allow greater coordination and cooperation between the armed forces of Kazakhstan, Uzbekistan and Kyrgyzstan and held its first exercise in September 1997. So how, the Russians asked themselves, were they to explain the fact that the United States sent a retired General, designated the Special Representative of the US Defense Secretary, to help the member states set up the organization? CENTRASBAT was clearly a part of an American scheme to gain control of the area, was the conclusion. Washington's onslaught on Central Asia's and the Caucasus' oil market was part of the same plan, though in this case, the Russians thought, the aim was not simply to wrest the region's oil trade from Russia, but to "gain undivided control of the world's oil and gas market." ${ }^{46}$

Russia had no doubt that if the United States was unable, for what ever reason, to control all or part of the region's oil resources itself, it would be quite happy to see Turkey, with its strong links in the region, do so in its stead. After all, in this new cold war, it made little difference which party to the alliance weakened Russia. The Russians probably agreed with Paul Wihbey, who observed that in the race for the Caspian Sea oil, the Americans had no more valuable ally than Turkey, who thanks to its geostrategic location, history and ethnic fabric could counteract Moscow, in ways and methods that Washington could not. Each dollar spent on Turkish defense and on increasing Turkey's power will, eventually, save much American blood and money, he added. ${ }^{47}$ All this explained, the United States support for planned pipeline through Turkey, which Moscow protested, would engender serious Russian financial losses and lead to "an escalated drift of several post-Soviet republics to Ankara, away from Moscow," which was, the Russians suspected, the whole point of the project anyway. ${ }^{48}$ Turkey, hoping to strengthen its position vis-à-vis Russia, fuelled the latter's fears of American-Turkish collaboration, Ismail Cem boasting that the United States and Turkey, seeing eye to eye on a wide range of strategic, political as well as fuelrelated subjects, strode hand in hand in Central Asia and the Caucasus. ${ }^{49}$

Russia, therefore, had every reason, economically, politically and strategically, to put a spoke in the wheels of the Baku-Tiblisi-Ceyhan project. Unfortunately 
for Turkey, Russia, who still wielded considerable political, economic and military influence in the region, had an almost infinite capacity to cause trouble. Georgia, for example, a key member of the project would, as Ankara knew and feared, "not be immune to Russian pressure or terrorist activity," designed to hamper to the pipeline's operation. If Russia failed in Georgia, it could always stir up more trouble between Armenia and Azerbaijan, and bring Azeri oil production to halt. ${ }^{50}$ Nor did the Russians necessarily have to indulge in dirty tricks. As a Black Sea state Russia could simply refuse to sanction the construction of a trans-Caspian underwater pipeline. Given that without Kazakh and Turkmeni oil the project was not economically viable, the Russian veto would probably be enough to kill off the entire project. In its battle against the Baku-Tiblisi-Ceyhan pipeline, Russia found an unexpected ally in Iran. Iran, too, opposed the project, both for economic reasons and because of fears that it would lead to growing Turkish and American influence in the Central Asia.

Fearing Russia's ability to block if not destroy altogether the BakuTiblisi-Ceyhan project, and not really wanting to embark upon an oil war with Moscow, Turkey and the United States decided that, rather than challenge Russia, it would be better to work with it. They, therefore, elected to involve Russia and, for much the same reasons, Iran in the project in a limited way. The United States suggested to Moscow that Russian firms should also export oil through the Baku-Tiblisi-Ceyhan and CPC pipelines. ${ }^{51}$ Turkey backed the American offer; first, because if accepted it would improve the chances of its project materializing; second, and no less importantly, it would remove one of the major sources of Russian-Turkish friction, always a Turkish priority. Indeed, having boasted of Turkey's close alliance with the United States, Cem was quick to reassure the Russians that they had nothing to worry about by pointing out that not "everything done to date [had] been a fight with Russia." ${ }^{52}$ This was also why Turkey was willing, with the United States' approval - the United States having a vested interest in defusing any potential conflict between Russia and its ally Turkey - to give Russia a stake on the AIOC consortium.

In order to persuade Russia to accept its offer, the United States played up the advantages, to the Russians, of doing so. Frederico Pena, the United States' Energy Secretary, played up the merits of the East to West energy corridor, which, he claimed, could serve and secure Russia's energy and commercial needs. For one thing, the AIOC and CPC could ferry oil from Azerbaijan and Kazakhstan to the Russian Black Sea port of Novorossiysk. For another, both consortiums would offer Russia better access to more attractive markets. ${ }^{53}$ Robert Gee, the United States' Assistant Secretary of Energy for Policy and International Affairs, added that Russian participation in the AIOC would render it a much larger share in the region's oil business than anything it could afford independently. The Baku-Tiblisi-Ceyhan pipeline specifically could benefit Russia financially, as using it would offset any financial losses Moscow incurred owing to lost haulage business. In sum, Gee concluded, Russia's participation in the AIOC, created a win-win situation from which everybody gained. ${ }^{54}$ Russia, 
though not entirely convinced, and still suspicious of the Baku-Tiblisi-Ceyhan project, accepted the invitation. The Russian oil company, LUKOIL joined the AIOC, thus winning a stake in the Azeri oil market. While Russia will probably still push hard for the Black Sea route, its membership in the AIOC and CPC consortiums may temper its opposition to the Turkish Baku-Tiblisi-Ceyhan project, enhancing the latter's prospects of success. ${ }^{55}$

By the beginning of the twenty-first century the odds on the Baku-Tiblisi-Ceyhan route materializing rose significantly. A sharp increase in oil prices, from under 10 dollars a barrel, in 1998, to 35 dollars a barrel, in September 2000, enhanced the route's commercial competitiveness vis-à-vis its Black Sea rival. The new restrictions on oil tanker traffic through the Straits, also improved the chances of the Mediterranean route, as Turkey knew they would. In addition, Turkey, in order to augment the route's attractiveness, considered offering the pipeline's users tax reductions and subsidies, instituting special tariff regimes and giving concessions on the price of crude oil as well as granting users rightof-way privileges. By the end of the 1990s, one of the few remaining clouds on the horizon was the request that Turkey absorb any construction costs above the initial 2.4 billion dollar estimate, a sum that could reach well over 1 billion dollars, which Turkey can ill afford. But, bearing in mind the future payoff, it would be money well invested, especially if Ankara can persuade the United States to foot part of bill. And it might well do, as the United States knows every cent spent on Turkey will, in the long run, serve American global, regional and economic interests. ${ }^{56}$

\section{Turkey and the United States}

Turkey's relationship with the United States during the 1990s was not all plain sailing, especially compared to what it had been during the fifty or so years of the cold war, when the United States considered Turkey, thanks to the latter's key geostrategic location, one of its most valuable assets in the battle against communist Russia. Anxious not lose such a vital ally, the United States, did all it could to keep Turkey sweet, by among other things selling it cut-price weapons or awarding it special economic privileges. It was even willing to overlook Turkey's various offences against human rights. Not that the Turks, being as eager to retain the United States' friendship as Americans were to keep theirs, needed much if any, as some would put it, bribing. The demise of the Soviet Union, in 1991, however, led to a slight shift in the United States' policy towards Turkey, the Americans believing that there was no longer as great a need to pamper Turkey. There was also the fact that after almost fifty years of cooperation the United States tended to take Turkey for granted, or at least that was how it appeared to disgruntled Turkish officials, who complained bitterly that the American Secretary of State had visited Damascus twenty-fourtimes, between 1992 and 1996, without bothering to call upon Ankara even once. ${ }^{57}$ Things 
improved somewhat during and in the immediate aftermath of the Gulf War, when the United States needed Turkey's help to wage its war against Saddam Hussein. Then came 1996, which reminded, indeed impressed on, Washington just how valuable and, possibly, irreplaceable an ally Turkey was.

This (1996) proved to be a very bad year for Washington in the Middle East. On the diplomatic front it seemed to have very few friends left in the region. It had no official diplomatic relations with Iraq, Iran, Libya, and Sudan, and its relationship with its few remaining allies was increasingly shaky. Saudi Arabia, extremely nervous at having to play host to a large number of American troops, would periodically raise the matter with Washington, in the hope of getting them out or at least significantly reducing their numbers. More worrying still, Americans, living or serving in Saudi Arabia, became the target of Islamic terrorists, who in June 1996 bombed the American base in Daharan, killing nineteen soldiers and wounding hundreds of others. Egypt, one of the United States' closest allies was not only increasingly critical of Washington's policies on the Arab-Israeli conflict, but also drawing closer to Libya, one of the United Sates regional bête noirs. Even Israel, perhaps the United States' staunchest Middle East ally, appeared, following the assassination of Yitzhak Rabin and election of the right-wing Benyamin Netanyahu to the post of Prime Minister, set on giving Washington a hard time. Netanyahu's entry into office did not augur well either for the peace process or American-Israeli relations. Not surprisingly, Turkey's friendship suddenly appeared increasingly precious, with the United States less and less inclined to take Ankara for granted.

In 1996, Washington was also finally forced to concede that the dual containment of Iran and Iraq had, at best, achieved only mixed results. It was not an entire failure as Iran and Iraq were still largely confined to their borders. Hit hard by American-inspired economic sanctions, they were too busy trying to survive to embark on a program of aggressive conquest. The arms and technological embargo made it much more difficult for them to develop or purchase unconventional weapons and long-range missiles; though, admittedly, their plans in this respect were not entirely frustrated. Nor were the two able to export their revisionist ideologies and policies. In sum, thanks to the policy of dual containment, Iran and Iraq no longer posed an immediate and serious threat to their neighbors.

On the other hand, both Saddam Hussein and the Iranian mullahs were still in power and showed no sign of loosening their ferocious grip on their countries. Nor had they renounced their vow to subvert the region, if not the world, shaping it according to their lights. Moreover, neither country, despite the United States' best efforts, was entirely isolated, either economically or politically. The Arab countries worried lest their own populations blame them for the sufferings of the Iranian and, above all, Iraqi people, and, wanting to avoid trouble at home, resumed contact with both countries. Advisable politically, it also proved an extremely profitable step economically. Certainly, Europe and Russia thought so as both eventually closed multibillion dollar trade deals with 
Iran. Iraq and Iran also exploited their burgeoning connections with the Arab countries, and neighboring Turkey, to circumvent the oil embargo. ${ }^{58}$ These trends continued well into the late 1990s. A rapprochement between Egypt and Iran occurred in 1998. In 2000, Jordan signed a free trade agreement with Iraq. The expulsion of the International Atomic Agency and United Nations (UN) inspection teams, charged with investigating Iraq's non-conventional and nuclear potential, increased the odds on the latter acquiring a nuclear bomb sometime in the future. The fact that the Iranian and Iraqi threat to region, though considerably diminished, remained, served to increase Turkey's worth. ${ }^{59}$

The rise of Islamic radicalism in the Middle East also helped remind Washington of the benefits of having secular Turkey as its ally. For years, Turkey had been the United States' sole reliable Muslim ally in the region. Then, in 1996, Turkey's Islamic Welfare Party came to power. Shocked and somewhat panicstricken, the United States wondered whether Turkey was not about to go the way of Iran. But if the chances of Turkey becoming an Islamic theocratic state were, as Washington realized once it had calmed down, extremely remote, it dared not risk such an eventuality occurring. In any case, Erbakan in power proved bad enough, as it seemed that the United States could no longer count on Turkey's friendship. Alarm bells began to ring throughout Washington once Erbakan began drawing parallels between PKK terrorism against Turkey and the United States' bombing of Tripoli in 1986. Small wonder, that Washington breathed a massive sigh of relief when Erbakan resigned and his government was replaced by a secular coalition.

Washington well aware that anger with and alienation from the West, due among other things to the EU's incessant criticisms of Turkey and the American Congress's embargo on the sale of weapons to Ankara, had fed the same radical religious sentiments in Turkey that had eventually brought the Welfare Party to power. Not wanting to repeat the Erbakan experience, the United States, was careful to avoid making the same mistakes again. The American Administration therefore, encouraged the EU to accept Turkey into its ranks. It also tried to lift or circumvent Congress's arms sanctions on Turkey. In January 1998, it revoked the suspension imposed on delivery of three frigates to Turkey, two of which were now given to Turkey outright, the third was leased to Ankara for a mere 9 million dollars. That same year, the Turkish air force received seven Americanmade KC-135R tanker aircraft. ${ }^{60}$ It could, therefore, be said that Erbakan marked a crossroads in American-Turkish relations, though not in the way he had hoped. His year in office, alerting the United States to the dangers of losing Turkey, inspired it to multiply its efforts to woo and regain the latter's confidence. After all, as Jesse Helms, Chairman of the United States Senate Foreign Relations Committee admitted: "The United States would be paralyzed in the Middle East without Turkey ... one of the most credible friendly allies of this country." ${ }^{31}$ 


\section{Shared interests}

After the nadir of 1996, Turkey and the United States became closer than ever. "If," the TDN boasted, "the temperature of Turkish-US relations could be measured by the number of Turkish delegations, it would register white-hot on any scale." With a great many interests in common, Turkey and the United States certainly had much to talk about, and high politics, security matters, diplomatic issues, strategic concerns, trade ventures, economic cooperation, cultural affairs and ecological questions all featured on the American-Turkish agenda. ${ }^{62}$ That Turkey was the United States sole reliable Muslim ally in the volatile Middle East has already been noted. But, Turkey's political and strategic worth to the United States went way beyond the Middle East. Straddling the Balkans in the West and Central Asia and the Caucasus in the East, Turkey formed an invaluable buffer zone between the West and these extraordinarily explosive areas. Moreover, Turkey often found itself in the very eye of the various ethnic and religious storms that rocked the Middle East, Balkans and Central Asia. Though, admittedly, reluctant to become too closely involved in these regional upheavals, and certainly unwilling to police either area for the West, Turkey, nevertheless, for reasons of its own, helped to defuse, contain, even end a large number of these actual and potential crises, crises which threatened both its and the West's wellbeing. Turkey also, when it served its interests, helped Washington fight several of its battles in the area - as it did, for example, in the race to corner the Caspian oil market - though always in tandem with the Americans. Indeed, Turkey, "able to counter the Russians in ways America couldn't," proved pivotal to the success of American policies throughout Eurasia. Turkey's achievements, there and elsewhere, underscored its continued and immense value as a partner and ally, despite the end of the cold war. More than one member of the Administration believed that, owing to Turkey's key geostrategic position, each dollar spent on Turkish defense would save double if not treble that amount in American blood and money. ${ }^{63}$

Happily, for Ankara, the United States invested in its beliefs. Throughout the 1990s Turkey received, on average, a generous 0.8 billion dollars of American aid a year. ${ }^{64}$ It also enjoyed a steady stream of American weapons. During the Clinton years, it obtained about 800 million dollars worth of weapons per annum, becoming one of the world's largest recipients of American arms, surpassed only by such long-term and valued American clients like Saudi Arabia, Taiwan, Israel and Egypt. Between 1990 and 1995, Turkey acquired 1.53 billion dollars worth of surplus American military equipment; second only to Greece, who, to Turkey's disgust, secured 1.8 billion dollars worth of equipment, but way ahead of Israel, who obtained only 718 million dollars worth. ${ }^{65}$ Over all, during the eight years of Clinton's presidency, the United States furnished Turkey with four times as many weapons, as it did between 1950 and 1983 at the height of the cold war. The Clinton Administration also made it much easier for American companies to compete for Turkish tenders for the sale of advanced 
weapons systems like the 4.5 billion dollar, 145 King Cobra advanced attack helicopters deal. The United States also became closely involved in Turkey's military training programs and participated in various Turkish military exercises; to a greater extent even then it did surpass those of its two other regional frontline allies: Egypt and Israel. ${ }^{66}$

NATO, too, provided a fruitful basis for American-Turkish cooperation. Following the collapse of the Soviet Union, the two countries banded together in an effort to expand NATO membership, beyond its current North AmericanWest European limits. During the Balkan wars, Turkey, with America's blessing, took part in various NATO operations to end the fighting and keep the peace in the region. In the early stages of the war in Bosnia, Ankara helped enforce NATO's sanctions against Serbia. After the war, it contributed troops to the NATO force in Bosnia, charged with implementing the Dayton Peace Accords. During the Kosovo crisis, Turkey joined the West in its efforts to deter Serbia and prevent it attacking Muslim Albanian refugees. In 1999, it sent 1,000 Turkish troops to the KFOR units in Kosovo. The United States was more than happy to have a predominately Muslim country involved in these and other similar operations in the region, operations that might otherwise have appeared to be exclusively Western, Christian enterprises. Turkey's participation was, Washington thought, doubly useful in that it reassured the local Muslim populations in Somalia, Bosnia, and Kosovo - that NATO and the other peace-keeping forces, unbiased and impartial, had their best interests at heart. It could also, the United States hoped, silence the Muslim countries' criticisms of the operations, and perhaps even persuade some of them to join the peace-keeping efforts in the Balkans themselves. Turkey saw its participation in the Balkan peacekeeping operations as way of helping the Balkan Muslims, descendants of the loyal subjects of the former Ottoman Empire, but without becoming unilaterally or too closely involved in the conflict. Given that very few, if any, Turks actually volunteered to fight alongside the Muslim Bosnians and Albanians, while the government refused, in principle, to be drawn in to the war, the government felt it necessary to at least be seen to be doing something for the local Muslim population. Participation in the NATO operations was the ideal solution. It put an end to any carping about Turkey's apparent indifference to its Muslim brethren's fate while, at the same time, winning it some very valuable points with the United State and West. ${ }^{67}$

Turkey's and the United States' interest in exploiting the Caspian oil reserves has been dealt with at length. But this was not the only economic interest the two had in common. The United States, having listed Turkey as one of the world's ten biggest emerging markets, began to encourage Americans to invest in its ally's market. Thanks to this and to the fact that Turkey's workforce has an impressive work ethic, but costs very little, American investment in the Turkish textile industry - Turkey's number one export business, accounting for 40 percent of all Turkish exports - and in various assembly-line manufactories - a Turkish speciality - rose spectacularly. Trade between the two counties also 
took off. In 1989, American-Turkish trade stood at 3.5 billion dollars, nine years later, in 1998, it approached the 6.3 billion dollars mark. Between 1995 and 1999 , the volume of trade between the United States and Turkey jumped by 28 percent. By the end of the decade the American market accounted for 8.8 and 8.3 of all Turkish imports and exports respectively. ${ }^{68}$ Turkey exported to the United States a wide range of products, including, despite heavy competition from China's dirt cheap products, textiles and steel, where Turkish exports increased by 17 percent, and even pasta, with Turkish pasta competing successfully with traditional Italian products. Hoping to expand their profitable trade relations even further, the United States and Turkey opened negotiations over the establishment of a free trade zone in the Adana-Yumurtalik district. Goods produced in the free zone would be exported to the United States, enjoying the special benefits applicable in the US-Israeli free trade agreement. ${ }^{69}$

\section{Areas of disagreement}

Like any marriage, however happy, Turkey's and the United States' relationship was not entirely quarrel free. The two allies disagreed, sometimes extraordinarily fiercely, over several issues; some minor, some major. Nevertheless, conscious of the benefits of cooperation, the two endeavored to keep, as much as possible, all friction between them to a minimum. At times they succeeded, at others, particularly when matters of conflicting national interests were involved, less so. But, even when deeply divided, and on the face of it pursuing widely divergent policies, the United States and Turkey always managed to find some common ground between them, and, if not, at least a way to rise above their differences.

Polychlorinatedbiphenyl (PCB) pollution in the Incirlik air base district, in northern Turkey was one of the minor, if extremely irritating, to Ankara at least, points at issue between Turkey and the United States. Polychlorinatedbiphenyl, a highly toxic substance found in oil used to cool down electric transformers, is a deadly environmental hazard. In humans, it may, among other things, cause liver dysfunction or severe damage to their reproduction systems. It is also a suspected carcinogenic. In fact PCB is so dangerous that it is no longer produced in the United States. After the closure of the joint American-Turkish military bases in Turkey, in the late 1980s and early 1990s, the oil used in the bases' transformers was sent to Incirlik where it was buried in metal containers. Unfortunately, the containers sprung a leak and the oil began to seep into the soil. Owing to the PCB's organic properties there was every chance that it would eventually filter into the area's subterranean waters and reach the Seyhan River, a main water source. Turkey had neither the technical expertise, nor the money needed to decontaminate the area and remove the PCB containers. The United States had both. What is more the United States, having put the PCB there in the first place, albeit it with Turkey's consent, was also, or so Ankara claimed, morally responsible for this environmental disaster. But when Ankara asked United 
States to clean up the mess, the latter, to the Turks amazement, refused, pointing out that as there was no signed agreement between the two on the matter, it was not legally obliged to do so. Dismayed, Ankara approached the Americans again, several times in fact, but to similar effect. Ankara thought Washington's attempt to duck its obligations by relying on legal quibbles especially unsavory, even contemptible, as in the United States, the Environmental Protection Agency ruled that all PCB leaks had to be dealt within forty-eight hours of their discovery. Yet, Turkey remonstrated, in Incirlik PCB has been seeping into the soil for over ten years "and we still cannot get anything done."

The closure of the American-Turkish bases provoked another disagreement between the two countries, this time over the Americans' decision to return various pieces of American military equipment home. The Turkish General Staff, arguing that equipment had been used by both forces, demanded right of approval over which items would be sent back. The Americans refused. The United States, on its part, hoping to cut costs, and, ironically, using the same argument as above, i.e. that both armies had used the equipment, demanded that all items awaiting shipment should be exempt from storage fees and custom duties. This time it was Turkey, loath to miss an opportunity to earn a considerable sum of money and annoyed with the Americans for not leaving behind more weapons, who said no. In 1997 the two, stubborn as ever, were still arguing over these issues. ${ }^{71}$

The United States' reluctance to buy a greater number of military components from Turkey - components used in building American weapons systems, which were then sold to Turkey and other countries - was another bone of contention between the two countries. Turkey would also have liked to sell more military equipment to the United States. The effect, in both cases would have been to give its military-industrial sector a tremendous boost. With money now available to invest in and develop the infrastructure necessary to produce weapons for its own use as well, Turkey would no longer have had to spend vast sums of money buying weapons abroad. Not only that but, it would no longer be dependent on foreign arms suppliers like the EU who often exploited this either to punish Turkey or force it to adopt policies considered detrimental to Turkish interests. Turkey would also have been able to develop its weapons export industry. Unfortunately, none of these dreams materialized as the United States was not inclined to offer Turkey a larger share in the American weapons market. This was extremely disappointing, but what made it really annoying was that the Pentagon, as Ankara discovered to its fury, was considering testing and buying defense equipment from over a dozen countries, including, Russia, but excluding Turkey. "Why," the TDN asked plaintively, "wasn't Turkey on the Pentagon's list?" One possible reason, according to Ankara, was the Americans' mistaken assumption that, "Turkey has no defence related material to sell and everything to buy from the United States." But, perhaps, Washington was also happy to keep Turkey dependent on it for weapons, which, like extra insurance, guaranteed that in the final count Turkey would always remain by the United States' side. ${ }^{72}$ 
Most of these areas of minor disagreement, involving as they did mostly technical and financial issues, mixed in with a bit of petty pride and prestige, though extremely vexing, could be, once the two countries set their mind to it, and with a little give and take on both sides, easily resolved. Not so the various points of dissent, between the Turkey and the United States which as a rule embraced matters of principle, national interest and policy. The United States' and Turkey's policies towards Syria were a case in point. Though both agreed that Syria was an extremely nasty, dangerous, terror-promoting country, divergent regional interests and perspectives led to several disputes over various aspects of the two countries' policies towards Damascus. Throughout the 1990s, Turkey repeatedly asked the United States to put more pressure on the Syria to stop supporting the PKK. The United States, not wanting to alienate Damascus too much and spoil any chances it may have of brokering a peace agreement between Israel and Syria, or, worse, end up pushing Syria into Iran and Iraq's arms, refused. Though, it must said that the State Department promised not to condemn Turkey, if it turned out that Ankara, as part of its campaign to persuade Syria to expel the PKK leader Abdullah Ocalan, was responsible for the series of bombings in Damascus in 1998, Turkey, for its part, strongly objected to any suggestion of removing Syria from the list of terror promoting countries. The United States, however, suspected that this would probably have to be done as part of the Israeli-Syrian peace agreement. Ankara pointed out, with justice, that while a peace accord may stop Syria supporting anti-Israeli terrorist groups, it would have no such effect on Syria's efforts to promote terrorism in Turkey. There was also some concern in Ankara lest the United States, believing that resolving the Turkish-Syrian water dispute in the latter's advantage would persuade Syria to grant Israel title to the Golan Heights' water resources, this being one of the major obstacles to peace between the two, and in its eagerness to bring the conflict between Syria and Israel to end, would press Turkey to modify its position in its quarrel with Syria over the rights to the waters of the Euphrates. Luckily for Turkey, owing to the deadlock in the Israeli-Syrian peace process, most of these possible sources of acute conflict remained latent, and did not seriously mar American-Turkish relations. ${ }^{73}$ This was not so in the case of Iran and Iraq.

In principle Turkey appreciated, even approved of, the logic behind the United States' dual containment policy. After all, it too had a vested interest in keeping Iran and Iraq as weak and as isolated as possible. Yet, at the same time, whether for economic or political reasons, Turkey often opposed and, in practise, ignored the sanctions imposed on both countries. In 1997, Turkey anxious to extend and diversify its energy sources signed a 23 billion dollar gas agreement with Iran. Most of the 228 billion cubic meters of Iranian gas was destined for Turkey's ever-growing gas market, the remainder some 10 billion cubic meters a year was to be sold to Europe, providing the Turks with a handsome source of revenue (see Chapter 4 for more details). In line with the agreement, a pipeline was built connecting the Iranian gas fields in Tabriz with the Turkish cities of Erzeum, Sivas, and Ankara. It was a sweet deal with only one snag: it 
violated the sanctions on Iran. Ankara, anxious not aggravate Washington particularly in view of the 1996 American Iran-Libya Sanctions Act, which imposed heavy penalties on companies or countries investing 20 million dollars or more in the Iranian or Libyan fuel market - insisted that it had not breached the embargo on Iran. Any Turkish investment in the project, it pointed out, had been confined to Turkish territory alone. ${ }^{74}$ This was a piece of legal sophistry the Americans found far from convincing. They disliked the gas agreement, which not only filled Iranian coffers, but flew in the face of the United States' declared policy of undercutting Iranian gas with gas from Central Asia. Luckily, for Turkey other than protesting strongly against the agreement, the United States did nothing. Washington, itself, for reasons of profit and politics, had tacitly approved several deals between various Central Asian countries and Iran. Turkmenistan and Kazakhstan, for example, had both concluded agreements with Iran, according to which the latter would process Turkmeni and Kazakh crude in its refineries in northern Iran and export the same amount of oil from its Gulf ports. Turkmenistan also agreed to supply Iran's northern cities with gas - a deal explained by the fact that most of Iran's gas fields are located in the south. As these and other similar agreements served to break Russia's monopoly over the Central Asian fuel market, the United States was quite happy to turn a blind eye to their obvious breach of the embargo on Iran. It would have been grossly hypocritical of Washington to punish Turkey for doing the same. ${ }^{75}$

As for Iraq, prior to the Gulf War, trade between Turkey and Iraq amounted to 2.5 billion dollars per annum, making Baghdad one of Turkey's four biggest trading partners. After the war and the institution of sanctions against Iraq, trade between the two dwindled to a mere 200 million dollars a year. Turkey was particularly hard hit by the oil embargo on Iraq. No longer allowed to transport Iraqi oil, it lost one of its most important sources of income. Turkey claimed that sanctions against Iraq had cost it some 35 billion dollars. Not surprisingly, Turkey sought to revoke or at least modify some of the sanctions against Iraq. It also, when it thought it could get away with it, circumvented them. The United States, though questioning Turkey's grim observation that "the first victim of the Gulf War was Iraq the second, Turkey," was generally sympathetic to Turkey's economic difficulties, some of which, it admitted, were indeed caused by the war. ${ }^{76}$ It therefore agreed to allow Turkey to ship limited amounts of Iraqi oil, in order to earn a little extra money as well and ease the unemployment situation in the country's poverty-stricken south. It also overlooked Turkey's agreement with Iraq to import crude oil in lieu of the Iraqi debts to Turkish businessmen. The deal stimulated the southeast's faltering transport business, as most of the oil was carried by Turkish trucks and created a large number of new jobs. It also, given that most of the profits went to Iraq's Turkish creditors in the area, injected a great deal of much needed money into the southeast. But this was not enough to satisfy Turkey, and soon with Ankara's tacit consent, thousands of Turkish trucks began carrying tens of thousands of barrels of smuggled Iraqi oil across Turkey. Oil smuggling was a highly lucrative business and the 
smugglers, unlike Ankara, were quite happy to see the sanctions remain in place. Oil smuggling also provided a neat solution to Turkey's problem with the UN oil embargo, which might otherwise have led to a serious rupture in relations with the United States. It allowed Turkey to deny that it was in breach of UN sanctions, while still doing business with Iraq and the United States to pretend that nothing was amiss, and the sanctions were strictly enforced.

Turkey also opposed the United States' bombing campaign against Iraq. It had agreed reluctantly to the launching of aerial attacks against Iraq from the Turkish base in Incirlik, and even then only after it had received a quid pro quo in the form of the oil for food agreement, which allowed Turkey to transport a limited amount of Iraqi oil and recoup some of its losses from the Gulf War. Unfortunately, however, the bombing tended to interfere with the smooth shipment of Iraqi oil, as well as disrupt the newly revived, if so far modest, Turkish-Iraqi trade. This added to Turkey's southeast provinces' troubles, as their economic regeneration was largely dependent on the oil transport business and trade with Iraq. But that was not the only reason Turkey objected to the bombing of Iraq. It seriously questioned the political objective behind the bombings, which was to destabilize Saddam's regime, bringing about its eventual demise. Blaming Saddam for the bombing, the Iraqi people would, or so the Americans hoped, either rise up in revolt, or provide the Iraqi opposition with sufficient grassroot support to enable it successfully to topple Saddam. Turkey thought the whole plan delusive and dangerous. It had no faith in the Iraqi opposition, which, it thought, was much too weak and divided to launch an effective coup. It also disliked, in principle, the plan's blatant interference in Iraq's internal affairs, which, it feared, could mark the beginning of new, unwelcome style of interventionist American foreign policy. "It may start in Baghdad," the TDN remarked, but "you never know where it ends. Why not Turkey?"77

Paradoxically, perhaps, Turkey was horrified, at the possibility, however, slim, that the American plan might succeed. Saddam's demise would probably result in Iraq's disintegration - a nightmare scenario as far as Turkey was concerned. Iraq's dissolution would rock the entire region. One of the few regional powers capable of counter-balancing Iran would disappear and, without Iraq breathing down its neck, Iran would be free to devote itself to undermining and subverting Turkey. It would also, in all likelihood, lead to the establishment of a Kurdish state, which encouraging separatist sentiments among Ankara's Kurds would threaten Turkey's territorial integrity. In sum, instead of welcoming the collapse of its arch-rival, Saddam, Ankara sincerely hoped to prevent it.

The incendiary question of Kurdish nationalism was the subject of a series of American-Turkish quarrels. Turkey consistently denied that there was such a thing as a separate Kurdish identity. Its Kurds, Ankara insisted, were simply Turks who happened to be Kurds. It deeply resented the United States' unwarranted pressure on it to recognize the Kurds' ethnic, cultural and linguistic identity. Washington's attempts to meddle in the Kurdish affair - an, it stressed, internal Turkish matter - was, Ankara complained, completely unjustified and 
unacceptable. It could also, Ankara feared, prove to be very dangerous, as Washington was convinced that the only solution to the Kurdish problem, was a political one, which could mean anything from giving them special rights to full autonomy. Having no desire to undermine the monolithic Kemalist nationalism upon which their state was based, or do anything that might threaten its territorial integrity, the Turks utterly rejected the American position. They pointed out that the Kurdish problem far from being an ethnic issue, was simply one of PKK terrorism, which once quashed, would no longer exist. It certainly repudiated any kind of a political solution to the problem, which might end up with Turkey divided into ethnic cantons. The United States disagreed, and, not surprisingly, Turkey's old Sevres phobia soon resurfaced, with Turkey suspecting that the United States was a party to Western Europe's plot to weaken and divide Turkey into small tribal units. ${ }^{78}$

The United States and Turkey were no less divided, and for much the same reasons, over the Kurdish "Safe Haven" in northern Iraq. Admittedly, like Turkey, the United States had no interest in creating an independent Kurdish state in northern Iraq. It did, however, want to see some kind of strong, united Kurdish entity in the region capable of putting Saddam under considerable pressure. To this end, it welcomed the Iraqi's Kurds' adoption of various statelike qualities, such as the holding of elections. It even toyed with the idea of Kurdish autonomy. The possibility of a future Iraqi federation, which would include a Kurdish state, was also bandied about. This proved too much for Turkey to stomach. At best, it thought, American policy would encourage its own Kurds to demand similar rights for themselves, at worst, it would end in an independent Kurdish state. A Kurdish state, even as part of an Iraqi federation, would in all likelihood adopt a policy of Kurdish irredentism, and, like a magnet, attract Turkey's own Kurdish citizens. Once again Turkey's Sevres complex raised its paranoid head, Ankara suspecting that Washington's advocacy of an independent Kurdish administration was in effect part of a broader scheme to weaken and divide Turkey. It led, as Kemal Kirisci observed, a great many Turks to regard the United States as "an enemy state rather than an old strategic ally." ${ }^{79}$

A Kurdish political entity, however diluted its form, might also, Turkey fretted, lead to the collapse of Saddam's regime and to the disintegration of Iraq. In such an event, even without an official Kurdish state in place, a political vacuum would emerge in northern Iraq, which the PKK would be quick to fill. The United States, however, if not anxious for Iraq's disintegration, longed, as noted, to see the back of Saddam. Seeing the Iraqi Kurds as a means to achieve this end, it began to forge close links with the Iraqi Kurdish opposition. Turkey, quite apart from the fact that it had no desire to see the collapse of Saddam's regime, or build up a Kurdish nationalist movement, thought the whole enterprise futile. It had no more faith in the two Kurdish leaders' ability to topple Saddam than it had in that of the Iraqi opposition forces. Moreover, as it pointed out to the United States, dependent on Saddam for fuel, part of which they sold abroad in order to earn money, Barazani or Talabani "have to be at least on speaking 
terms with him [Saddam]. So to expect Barazani and Talabani to get into an adventure against Baghdad" with no assurance of its success "would be foolish," in the extreme. ${ }^{80}$ The whole project, Ankara concluded, was a pipe dream. The United States would be far better off adopting Turkey's sensible and practicable policy of maintaining a weak Kurdish front, just about strong enough to worry or irritate Saddam, but no more.

The Armenian question proved no less of a thorn in the side of American-Turkish relations than the Kurdish problem. The powerful American Armenian lobby persuaded Congress to pass a bill acknowledging that the Ottoman Empire was responsible for the Armenian genocide during the First World War. Quick to respond, to this, to its mind, outrageous accusation which certainly had no basis in reality, the Turkish National Assembly voted to erect, in Ankara, a memorial commemorating the persecution of the American Red Indians by both the United States' white settlers and its government. It was well within its rights to do so as some of the Red Indian tribes, the Apaches for example, or so Turkish nationalists claimed, indulging in a little fiction-building of their own, had Turkic roots. While Washington could afford to brush off the threat, however embarrassing, to build a monument commemorating the sufferings of the Red Indians, it could not ignore the bill's possible political and strategic consequences. Hypersensitive to any accusation that it was guilty of the mass murder of well over 1 million Armenians during the war, Turkey was liable to overreact, and tie up the United States' policies throughout the Middle East, the Balkans and Central Asia. It might do so even though in some cases cooperating with the United States was in its best interests, so that in sense it would be cutting off its nose to spite its face. A prime example of this was the Turkish threat to stop working in tandem with the Americans in the Caspian oil market. It would certainly, the Administration thought, persuade Turkey to withdraw its support from the, in its view, more problematical aspects of American policy, which until now it had supported only extremely reluctantly - the air strikes against Iraq being a case in point. In 1999 alone, the United States launched, from Turkish bases, over 150 air strike against Iraqi targets - mostly radar installations and anti-aircraft batteries, which threatened the American planes patrolling the safe zones in northern and southern Iraq. Not only could Turkey put a stop to this, but it could also expand its trade relations with Iraq and Iran, further weakening the United States' already fragile dual containment policy. In short, the bill, the Administration realized, could imperil the United States' efforts to fight "drugs, thugs and terror" in the Middle East.

What is more, Turkey, incensed, appeared set to embark down this highly unnerving road. It warned that it would resume railway links between Baghdad and Turkey. It initiated agreements for the importation of Iraqi crude, and it was a hardly a coincidence that just as the bill was being discussed in Congress, Turkey suddenly decided to upgrade its mission to Baghdad to that of a fullblown embassy. Ankara denied that there was any connection between the two issues but the Administration, aware that it would achieve nothing in Iraq or 
elsewhere "unless the Turks were on the same page," took the hint and forced Congress to withdraw the bill. ${ }^{81}$ But the issue did not to disappear. In January 2001 the French National Assembly accepted a bill that attributed the massacres of the Armenians to the Turks. Accordingly, the city of Paris decided on building a monument in memory of the Armenian victims. Ankara retaliated economically, barring French companies from participating in Turkish tenders, and cancelled the procurement of security items from France. The Lord Mayor of Ankara decided to retaliate by building a monument in memory of the Algerians killed by French troops. "Similar measures would be taken against any country that would link the Armenian plights to the Turks," warned Turkish officials. ${ }^{82}$

Given the headache the US Congress bill had caused it, Washington was determined, not, if it could help it, to reopen the Armenian issue ever again. Thus, Turkey scored a double victory. It not only killed off the present bill, and probably any other similar bill in the future, it also drove home to the Administration the fact that not only did it need Turkey, but, no less importantly, that it could not take Turkish cooperation for granted. In the case of the Armenian bill, by allowing Turkey to prove, once again, that it was in nobody's pocket, it induced the Americans to redouble their efforts to woo Ankara, and treat it and its interests with greater respect.

\section{Human rights}

One of the biggest issues liberal Washington had to take up with Ankara during the 1990s was the latter's human rights policies. In 1977, the United States' State Department presented Congress with the first of a series of annual reports on the human rights situation throughout the world. Over the years, the portion of the report devoted to Turkey grew consistently larger. Moreover, if at first, the State Department's criticisms of Turkey were relatively mild, by the end of the 1990s it pilloried Turkey's human rights policies, which it fiercely and uniformly condemned. Nor was the State Department exaggerating. In 1999, Turkey topped the European Court of Human Rights' list of thirty-seven countries accused of violating human rights. Out of the 7,771 complaints registered in the court, Turkey received a record 1,825 complaints, way ahead of Italy, who was second in line with 1,191 complaints. ${ }^{83}$ The complaints specified, inter alia, beating, assault, and torture. The 1998 report of the Human Rights Association, the Istanbul Branch, listed the most common methods of torture at Turkish police and gendarmerie stations, as threatening with rape, disappearing under torture, torturing the victim's family, displaying a pregnant woman nude to her husband, etc. There were also "common" methods such as beating, electric shocks, and hitting the victim's head with an iron bar.

In view of the large number of politically motivated arrests in Turkey, the country's detention and prison systems came under intense international scrutiny and criticism. Turkey was accused of breaking of the rules of custody 
by, among other things, assaulting, beating, and even torturing prisoners and detainees. Suspects could be held for up to fifteen or thirty days without arraignment. They could be questioned without legal counsel present. The practise of torturing detainees, both during police questioning and after, was fairly widespread. According to Human Rights Watch/Helsinki, between September 1980 and September 1995, 445 people had undergone torture and died in Turkish detention centers. Human rights associations report that 80 percent of women serving time in Turkish prisons were raped. There are 72,000 prisoners in Turkey's heavily dense prisons. As Time found, some prisoners share their beds with others, and most prisons are dormitory-style in acute need of improvement to make them suitable for the accommodation of human beings. Attempts by the authorities and the inmates to change conditions often result in riots, hunger strikes, death-fast, and bloodshed. The authorities reasoned they could better maintain order and discipline by reducing numbers and the transfer of convicts from large, dormitory-style facilities to new single or triple-bunk cells. However, the prisoners expressed fear of being moved to smaller cells, even if in new, more comfortable buildings. The relative isolation, they argued, would leave them at the mercy of their jailers, who could more easily bully or torture them. "There is safety in numbers," the inmates said. ${ }^{84}$ In early 2002 there were more than 100 people on hunger strike in a dozen Turkish prisons. Those on the death-fast track took only liquid and vitamins but at a rate that permitted them to waste away at a very slow rate. ${ }^{85}$

The State Department 1999 report on human rights, noted that though the Turkish constitution allows for freedom of speech and the press, and though there is no official censorship in Turkey, in practise both freedoms are severely curtailed. Anyone deviating from the official government line, when discussing the Kurds, the status of Islam in the country, the military's role in politics, the Armenian question, or Turkish-Greek-Cypriot relations, risked censure, if not imprisonment. ${ }^{86}$ In 1996, Amnesty International and the New York based Committee for the Protection of Journalists (CPJ) accused Turkey of harassing, intimidating and imprisoning human rights activists, lawyers and journalists, whose only crime was to voice ideas contrary to government policy. Between 1994 and 1996, Turkey had the dubious honor of being the country that had arrested the most journalists, its rivals for the title being those well-known paragons of liberalism: Ethiopia, communist China, Kuwait, Nigeria and Myanamer (Burma). ${ }^{87}$ Nor have things improved much since. According to PAN, the International Organization of Authors and Poets, after China, Turkey boasted the largest number of imprisoned writers and journalists in the world. It had incarcerated 132 writers for thought crimes; ordered the closer of 152 associations, newspapers and magazines all of which were guilty of criticizing government policy, while Turkish officials had banned 331 subversive books and newspapers. ${ }^{88}$ In July 1999, the Turkish Press Council published the names of fifty-five journalists who, having written articles deemed harmful to the Turkish state, were either in prison or facing criminal charges. The Voice of America 
revealed that over the past seven years twenty-five Turkish journalists had died in highly questionable circumstances. ${ }^{89}$ To its immense credit, the Turkish press, despite the risks involved, remained courageously defiant. Often, the Turkish journalists sole, if meager, defense against government harassment was to report on the government's gross violations of the principle of free speech, usually at the cost of their jobs if not their freedom..$^{90}$ Nevertheless, giving no quarter, they continued to criticize mercilessly both government and army policies. Nothing and no one were exempt from the Turkish press's ruthless scrutiny, which as random perusal of both English and Turkish journals shows, was not inclined to voice its disapproval delicately or be less forceful in its views.

The Kurds and the advocates of Kurdish nationalism came in for some particularly rough treatment. Until 2000, there were no legal publications in Kurdish in Turkey and anyone daring to voice an opinion sympathetic to Kurdish nationalism risked being arrested automatically. According to Amnesty International's 1996 report, the government consistently violated the rights of the members of the pro-Kurdish People's Democracy Party (HADEP). Defiant, Kurdish activists continued to publish material on their people's plight and lack of rights, distributing it through the Kurdish underground network. The government's violation of Kurdish rights, particularly during its war against the PKK, was strongly criticized abroad. Amnesty International, the New York based CPJ, and the Human Rights Watch/Helsinki all highlighted Turkey's human rights offenses in the Kurdish southeast. However, to be fair, they devoted equal space to PKK atrocities against civilians, men, women and children, which, they admitted, were among the most viciously obscene violations of human rights on record. ${ }^{91}$ The State Department's 1999 report pinpointed the Kurdish southeast as the area in most need of change in terms of Turkey's human rights situation. Things improved a little, after the end of the PKK war in 1999, when the government allowed the publication of at least a few works in Kurdish. However, sensitive as ever about the subject of Kurdish nationalism the government periodically cracked down on individuals and publications too openly sympathetic to the Kurdish cause..$^{92}$

Islamic activists were also victimized by the state. Despite sanctioning and even, to a degree, encouraging the growth of political Islam, the Turkish authorities, extremely sensitive to the threat political Islam posed to the country's secular identity, took, when necessary, appropriate action - or as the State Department would have it, inappropriate action - to frustrate it. The State Department's 1999 report noted and strongly criticized the ten-month prison sentence imposed on Istanbul's mayor, Recpe Tayyip Erdogan, found guilty of calling for a religious insurrection in speech he gave in Siirt, in December 1997. The speech included the following verse from a 1920s folk song: "the mosques are our barracks, the believers are our soldiers, the minarets are our bayonets, their domes are our helmets and the faithful our army," which apparently was enough to convict Erdogan of seditious activity. ${ }^{93}$ The report also censured the Turkish Constitutional Court's decision to dissolve the Welfare Party for its 
supposed infringements of the state's secular constitution. It also condemned the ban imposed on several of the party's leaders, including Erbakan, barring them from taking an active part in Turkish politics. Nor was that the end of it. In June 2001, the Constitutional Court dissolved the Islamic Virtue Party for ostensibly anti-secular activities. In January 2002, the Constitutional Court ruled that Erdogan, already on the government's hit list of subversive Islamic activists, could not head any political party. The decision prevented him from entering parliament and scotched his plans to form a new moderate Islamic party, by the name of the Justice and Development Party. As earlier noted, the Islamic parties were not the Constitutional Court's only casualties. Since 1963, the court had disbanded some twenty-two political parties for undermining the constitution's secular articles or violating the principles of democracy.

Turkey was severely criticized for being too lax and not disciplining wayward prison wardens and policemen. It failed to stop them from violating suspects' and prisoner's rights and did not punish them appropriately when they did. The few who were brought to trial, their crimes, such as beating a detainee to death, being too shocking to ignore or impossible to cover up, were sentenced, at the most, to seven and half years in prison. With time off for good behavior, it meant that they would only spend two to three years in jail..$^{94}$

The State Department's 1999 report highlighted three areas that were in urgent need of radical reform. The first focused on Turkey's consistent failure to observe the principle of free speech and expression, including the right of religious freedom. The second concerned the state's odious treatment of human rights activists, including non-governmental organizations, doctors, lawyers, even parliamentarians who were subjected to constant censure, harassment and imprisonment. The third related to the handling of political detainees. The report expressly demanded that Turkey decriminalize free speech, release journalists and parliamentarians imprisoned for political reasons, put an end to the practise of torturing suspects during interrogation and after, and indict officers found guilty of doing so. Turkey should also allow the various non-governmental organizations, shut down for political reasons, to reopen. The report urged the government to democratize the country's political system even further and permit more people holding different views to partake in the political process, lift the state of emergency in the southeast, and resettle the refugees displaced by its war against the PKK. ${ }^{95}$

The State Department's censure of Turkey was nothing compared to the American human rights lobby's impassioned condemnation of Turkey's human rights policies. The latter not only condemned Turkey violations of human rights, but demanded that Congress and the Administration take action to stop this state of affairs. To this end, it joined forces with other anti-Turkey, nongovernmental organizations and lobbies, who had criticisms of Turkey. For example, these bodies regularly accused Turkey of supporting the Azeri army, obstructing Western aid to Armenia, violating the country's Greek and Armenian minorities' religious freedoms, and supplying weapons to Chechen rebels. 
Forming a large pressure group, these organizations pressed Congress to enact anti-Turkish legislation. The human rights lobby also pressed Congress to cut all aid, specifically military aid, to Turkey. These requests, purposely phrased in such a way as to show Turkey in the worst possible light ("Ankara was blackmailing Washington, begging for more weapons by using its poor economic records"), did not win it many friends in Congress. ${ }^{96}$ Still, in 1997 and 1998, to the anti-Turkish lobby's delight, Congress decided to cut subsidies on arms exported to Turkey, on the grounds that these weapons could not be used against non-combatants during Turkey's war against the PKK.

By the end of 1990s, the threat to reduce military aid to Turkey in an effort to persuade it to reform its human rights policies, or any other of its policies for that matter, was no longer the potent weapon it had been. For one thing, Turkish firms were producing more and more military modules themselves, including a number used in American weapon systems. Less dependent on American modules, Ankara was able to shrug off threats to stop sending it spare parts if it did not improve its behavior. For another, Turkey, or so the human rights lobby claimed, deliberately announced an amazing 150 billion dollar arms procurement program, which, as Turkey intended, got the global and American arms market "salivating" ov over the prospect of huge long-term profits. Turkey, so argued the lobby, had in effect, enlisted the help of the allpowerful world arms industry, which exerted heavy pressure on the American Administration and Congress, as well as governments around the world, to overlook its human rights violations. Whether or not this was Turkey's aim in announcing the program, the fact was that within a short time of the announcement the United States lifted several bans on the sale of weapons to Turkey.

As noted by Kemal Kirisci, Ankara, convinced that Congress was endemically hostile to Turkey, expected the stronger Congressional role in foreign policymaking in recent years to work to Turkey's disadvantage since its main advocates were in the Defense and State Departments and National Security Council. Congress's actions during the 1990s certainly appeared to bear out its forebodings, and the Secretary General of the Turkish General Staff, General Erol Ozkasnak, expressed concern lest the "the speed of our [Turkish-American] relations will not be halted by some Congress members." Turkey thought that the Administration had failed it in this respect and had not done enough to ensure a friendlier Congress. But, confident that the chances of its human rights record having any practical effect on the Administration's policy were extremely remote, the State Department's periodic censure did not particularly worry it either. After all, in the State Department, as in the Defense Department and the National Security Council, all of whom were Ankara's "main advocates ... strategic interests regarding Turkey usually prevail."98

The United States continued, throughout the 1990s, to sell arms to Turkey, its human rights policies not withstanding. In the aftermath of the Gulf War the Republican Bush Administration promised Turkey a vast amount of weapons. The Democratic Clinton Administration not only made good its predecessor's 
pledge but made a few of its own. In fact, in terms of overall value, 47 percent of American arms shipments to Turkey, between 1984, the year the war against the PKK began, and 2000, took place under President Clinton. Clearly, the Clinton Administration despite its seemingly greater commitment to human rights issues, apparently, saw no reason to change the United States' policy on the sale of arms to Turkey. ${ }^{99}$ This was, in part, because, like all American Administrations, it was sensitive to Turkey's singular internal and external circumstances. Threatened from within by Islamic and separatist movements, and living in an unstable and unpredictable region, surrounded by states who would like nothing better than to weaken and destabilize it, Turkey, the Americans realized, often felt that it had no choice but to defend itself, without necessarily paying too much attention to liberal niceties. The United States understood and sympathized with Turkey's - as it saw it - ongoing fight for its existence, even if the specific form it took did not always accord with Western or democratic values or even Western policy. Hence Washington silence when Turkey's Generals effectively toppled Erbakan from power, contrary to the rules of Western democracy. As for the Kurds, Washington, despite its basic endorsement of the principle of Kurdish nationalism, branded the PKK a terrorist organization, backed the idea of a Turkish security zone in northern Iraq, and approved, tacitly, of Turkey's search-and-destroy missions against the PKK bases in the area. It also sanctioned, and perhaps even took part in, the Turkish operation to capture Abdalluh Ocalan, an operation that skirted dangerously close to the edges of international law.

But, perhaps, above all, it was the Administration's appreciation of Turkey's value as an ally that ultimately persuaded it if not to ignore Turkey human rights offences, then at least not to let them affect its working relationship with Ankara. In a region riven by ethnic strife, that was politically unstable and economically weak, as well as scarred by terrorism and generally hostile to the West, Turkey, whatever its faults, was a virtual rock of stability. It had already demonstrated its worth in the Gulf War, in Bosnia and in Kosovo, and with new conflicts brewing in the Middle East, the Caspian and Caucasus, the United States needed its Turkish ally more than ever. It certainly had no desire to antagonize it unduly on issues relating to human rights violations. And when that proved impossible owing to Congress's intervention, it exploited the burgeoning Israeli-Turkish relationship either to transfer aid to Turkey indirectly or convince Congress, which was as a rule pro-Israeli, that by helping Turkey it was also helping its ally Israel. ${ }^{100}$ In any case, as the Administration pointed out to Turkey's critics, compared to some of its neighbors - Iran, Iraq, Syria, and even Egypt and Saudi Arabia, among the West's principal allies - Turkey, a constitutional, secular country, which shared many of the West's goals and values, and whose political and social models were grounded in Western principals, was a paragon of democratic virtue.

The Administration was also convinced that harping too much on Turkey's dubious human rights policies and using threats in order to blackmail Turkey 
into reforming itself was, ultimately, counterproductive. It believed that there was a direct link between the EU decision, in 1997, to reject Turkey's membership application and the latter's consistently poor human rights record. Turkey, it argued, having been rebuffed by the EU, at Luxembourg, had little incentive to improve its human rights performance. According to the United States, instead of using the prospect of EU membership as a stick with which to beat Turkey over the head, the Europeans should use it as a carrot in order to encourage Ankara to reform. It believed that the promise of admission would inspire Turkey to overhaul its political, social, judicial systems, and bring them in line with Western practises. After all, it had worked before with Spain, Portugal and Greece, why not with Turkey? Yet, the Europeans, unconvinced, refused to listen, and were resentful that Washington was trying to tell them whom they should admit to their club. They turned a deaf ear to the American warning that the Turkish government, Turkish liberals, intellectuals as well as the public, believing that Turkey, the victim of European bias, was blatantly discriminated against, would, increasingly frustrated, eventually turn their backs on the West altogether. Still the United States did not give up and throughout the late 1990s urged the EU to admit Turkey into its ranks, while criticizing the Europeans' "shameless and short-sighted" policies and acknowledging that "they [the Turks] had every right to feel betrayed." ${ }^{101}$

Not that the Administration was blind to Turkey's human rights transgressions. It admitted that there were problems in this respect and periodically impressed on Turkey that it expected it, as a democracy, to heed its appeals to reform itself. By the end of the 1990s, Administration officials were happy to announce that there was some "reason for optimism" in this respect as there had been some definite and obvious "changes for the better" in Turkey's human rights performance. Amnesty International upheld the American assessment. The 1999 Amnesty International report on Turkey noted that there had been, since 1995, a significant drop in the number of Turkish prisoners who suffered ill treatment or had undergone torture, as well as fewer disappearances and extra judicial executions. This was partly due to the long overdue change in Turkey's habeas corpus laws. Since 1996, detainees had the right to legal counsel within four days of their arrest, the right to have a lawyer present during interrogation, and the right to have a lawyer accompany them throughout their detention period. The gradual decline in the war against the PKK also had a positive impact on Turkey's human rights situation. In addition, the report acknowledged that for the past few years "there has been much talk, apparently sincere," in Turkey of new laws, programs and regulations to improve human rights. But, at the same time, the report warned that much more had to be done - including, and above all, chastising and punishing officials guilty of human rights offences before Turkey could claim to have set right its human rights record. ${ }^{102}$

By the end of 1999 the United States, pleased with Turkey's efforts to reform, believed that henceforth things could only get better. Administration officials pointed out that Ocalan's capture bringing the war against the PKK to 
an effective end meant that " 80 percent of the excuses of the Turkish government" as regards "rights abuses disappeared." ${ }^{103}$ The PKK's unilateral declaration of a cease-fire, in February 2000, gave hope for even further improvement, as did the EU decision, in December 1999, at long last to accept Turkey's membership application. ${ }^{104}$ Thus, 1999 was seen as a turning point in Turkey's human rights performance, which had long blighted American-Turkish relations. Yet, in the final count, Turkey's human rights practices never really endangered Turkey's close association with the United States; Washington simply had too much at stake to risk losing Turkey's friendship. The Administration was also willing to allow Turkey a great deal of leeway, settling for less than absolute and instant reform. Work in progress was quite enough to satisfy its liberal conscious, which was why in July 1999, the American Secretary of Defense, William Cohen, declared at a press conference in Ankara that he saw nothing to prevent the pending transfer of American arms to Turkey.

\section{Close allies - common ground}

The manner in which the United States dealt with Turkey's human rights records was, in many ways, representative of the nature of American-Turkish relations as a whole. Despite its disapproval of Turkey's human rights policies, Washington, for whom Turkey in the 1990s was as important an ally as it had been in the days of the cold war, did not let its, often justified, reproofs stand in the way of close cooperation with Ankara. In like manner, Turkey, though often exasperated with United States', to its mind, selfish and myopic policies, nevertheless continued to collaborate closely with Washington. Situated in a dangerous region and surrounded by potential foes, Ankara knew that it best hope for the future lay in cleaving as closely as possible to the United States. Moreover, the two countries had too much in common and too many joint interests at stake including the need to curb Russia's overweening influence in Central Asia; to stem Iranian fanaticism; to check Iraqi extremism; to end, or at least limit, the possible repercussions of the many political crises and ethnic wars in Central Asia and the Middle East; and to secure a regular energy supply - to allow petty, and sometimes not so petty, disagreements to come between them. As a result, both were careful not to let any differences of opinion overshadow their, hitherto, extremely fruitful association. They were ready, instead, to indulge in a little give and take in order to ensure that at the beginning of the twenty-first century their alliance remained as strong, as solid, and as effective as ever.

\section{Notes}

1 Brent Sasley to Ms. Kinory, MERIA News, 13 and 25 November 1998.

2 Jacob M. Landau, Pan-Turkism: From Irredentism to Cooperation, Bloomington, IN, and Indianapolis, IN, Indiana University Press, 1995, p. 201; Nadir Devlet, TDN, 12-13 April 
1999. Devlet was the director of the Turkic Studies Institute at Istanbul's Marmara University.

3 Brent Sasley to Ms. Kinory, MERIA News, 13 and 25 November 1998.

4 Landau, Pan-Turkism. p. 201; Nadir Devlet, TDN, 12-13 April 1999.

5 Stephen J. Blank, "The Eastern Question Revived: Russia and Turkey Contend for Eurasia," paper presented in a conference on The Muslim Republics of the Former Soviet Union, Tel Aviv University, 12-14 October 1993, p. 25; Gareth Winrow, Turkey and the Caucasus: Domestic Interests and Security Concerns, London, Royal Institute of International Affairs, 2000, pp. 1, 19, 34.

6 New York Times, reprinted in Ha'aretz, 3 December 1999.

7 Necdet Pamir, “The Future Prospects of the Euroasian Corridor: Is there a Future?," paper presented at a conference on Building a Secure Eurasia in the 21st Century, Istanbul, 8-9 June 2000; James M. Dorsey, Wall Street Journal, 15 December 1997.

8 Necdet Pamir, "The Future Prospects of the Euroasian Corridor: Is there a Future?"

9 Cumhur Ersumer, Turkish Minister of Energy and Natural Resources, Milliyet, 23 May 2000; Sabah, 24 May 2000; Robert O. Freedman, "Russia’s Middle East Ambitions", Middle East Quarterly, Vol. 5, No. 3, September 1998, p. 32.

10 Ibid.

11 Freedman, "Russia’s Middle East Ambitions," p. 32; Winrow, Turkey and the Caucasus, p. 45; Suha Bolukbasi, "The Controversy over the Caspian Sea Mineral Resources: Conflicting Perceptions, Clashing Interests," Europe-Asia Studies, Vol. 50, No. 3, 1998, p. 403; Greek Ministry of Press and Mass Media, Secretariat General Information, Greece: Your Strategic Partner in the New Millennium, Athens, Ministry of Press and Mass Media, 1999, p. 64.

12 Yucel Guclu, "Regulation of the Passage through the Turkish Straits," Perceptions, Vol. 6, No. 1, March-May 2001, p. 128; Turkish Probe, 30 November 1997; Turkistan Newsletter, Vol. 98:2-012, 22 January 1998.

13 Guclu, "Regulation of the Passage through the Turkish Straits," pp. 127-128.

14 For information on the Bosporus hazards see Brent Sasley, "Turkey Energy Politics in the Post-Cold War Era," MERIA Journal, Vol. 2, No. 4, 1998; Yuksel Inan, "The Current Regime of the Turkish Straits," Perceptions, Vol. 6, No. 1, March-May 2001, p. 114; Douglas Frantz, "The Busy Bosporus is Likely to Get Even Busier," New York Times, 28 January 2001.

15 Stephen Kinzer, "Turks Fearful of an Oil Disaster as the Bosporus Gets Busier," MERIA Seminar: New York Times on Oil Transport through the Bosporus, 11 January 1998; Sasley, "Turkey Energy Politics in the Post-Cold War Era." See also Inan, "The Current Regime of the Turkish Straits," pp. 99-116; Guclu, "Regulation of the Passage through the Turkish Straits," pp. 117-134.

16 Douglas Frantz, "The Busy Bosporus is Likely to Get Busier," New York Times, 28 January 2001.

17 Harun Kazaz, TDN, 17 January 1998; Kinzer, “Turks Fearful of an Oil Disaster as the Bosporus Gets Busier."

18 Guclu, "Regulation of the Passage through the Turkish Straits," p. 133.

19 For information on the risks navigating the Straits see Sasley, "Turkey Energy Politics in the Post-Cold War Era”; Inan, "The Current Regime of the Turkish Straits," p. 114; Frantz, "The Busy Bosporus is Likely to Get Busier"; Guclu, "Regulations of the Passage through the Turkish Straits," p. 127 .

20 ARI Movement, CD ROM on the "Perils of Oil Transport through the Turkish Straits," MERIA Turkishlist, 16 November 1999.

21 Inan, "The Current Regime of the Turkish Straits," p. 115; Rapport Annuel sur le Mouvement des Navires a Traverse les Detroits Turcs, 1998, 62eme annee, 1998, Ankara, 1999, pp. 49-52. 
22 Ibid.

23 Kinzer, "Turks Fearful of an Oil Disaster as te Bosporus Gets Busier"; Sasley, "Turkey Energy Politics in the Post-Cold War Era"; Guclu, "Regulation of the Passage through the Turkish Straits," pp. 125-126.

24 Robert O. Freedman, "Russia’s Middle East Ambitions," p. 38.

25 Ibid.

26 G. Winrow, "Turkey and the Newly Independent States of Central Asia and the Transcaucasus", MERIA Journal, Vol. 2, No. 5, 15 June 1997.

27 Freedman, "Russia's Middle East Ambitions," p. 39.

28 Federico Pena, US Secretary of Energy, testimony before the US House of Representatives, International Relations Committee, 30 April 1998.

29 Ismail Cem, interview, TDN, 31 July 2000.

30 Turkish Probe, 11 April 1999; Robert W. Gee, Assistant Secretary of Energy for Policy and International Affairs, Testimony before the US House of Representatives, International Relations Committee, Subcommittee on Asia and the Pacific, Washington, DC, 12 February 1998.

31 Federico Pena, US Secretary of Energy, testimony before the US House of Representatives, International Relations Committee, 30 April 1998.

32 Turkistan Newsletter, Vol. 98:2-35 (1998).

33 Federico Pena, US Secretary of Energy, testimony before the U.S. House of Representatives, International Relations Committee, 30 April 1998.

34 Turkish Probe, 11 April 1999.

35 Federico Pena, US Secretary of Energy, testimony before the US House of Representatives, International Relations the Committee, 30 April 1998. When speaking to the Committee Pena underlined the fact that American oil companies "employ the world's highest environmental protection practices and technologies" which meant that "their involvement will help ensure that development in the Caspian region achieves a desirable balance between maximizing production and environmental stewardship." $\mathrm{He}$ alluded only in passing to the huge profits these companies stood to make.

36 Paul Michael Wihbey, “The Southern Eurasian Great Game," Institute for Advanced Strategic and Political Studies, Jerusalem, IASPS Research Paper in Strategy, Vol. 8 (1999), p. 14 (Hebrew).

37 There is an ongoing dispute between the Caspian Basin's five littoral states, Azerbaijan, Kazakhstan, Russia, Turkmenistan, and Iran, over the sovereign rights to the oil fields in the Caspian Sea. Azerbaijan, Kazakhstan, and Turkmenistan claim that the Caspian, a large inland sea, is in fact a lake, in which case, according to tradition and precedent, the littoral states must either divide its resources equally among them, and/or exploit them by mutual consent. In practise however, owing to these states' widely divergent national interests, neither option proved feasible. This being the case, Azerbaijan, Kazakhstan, and Turkmenistan argued that the sea underwater resources should be apportioned between the littoral states in the following manner: straight lines were to be drawn from the two outmost points of each state's coastline. These lines would continue out into the sea until they eventually diverge, dividing the Caspian Sea into various sized segments. Each country would have the rights to the oil within its portion of the sea. Iran and Russia insist that the Caspian is a sea and that under the 1982 UN Convention on the Law of the Sea, each littoral state owns the sea's resources within a 12-mile limit. It also possessed an exclusive economic zone for a further 200 miles. Moscow and Tehran claim ownership over the sea resources in a 4-mile area, beyond which they declare the resources of the Caspian must be shared. Their attitude is understandable given that their coastlines are relatively small so that they stand to gain much more if the Caspian is declared a sea rather than lake. See R.C. Longworth, "Destitute Plum of Caspian Has Many Suitors," Chicago Tribune, 9 February 1998; Turkistan Newsletter, Vol. 98:2-030, 17 
February 1998; Turkistan Newsletter, Business, Vol. 98:019, 2 March 1998; Suha Bolukbasi, "The Controversy over the Caspian Sea Mineral Resources," pp. 408-410; Sasley, "Turkey Energy Politics in the Post-Cold War Era."

38 The AIOC members are the United States' AMOCO, PENNZOIL, UNOCAL and Exxon oil companies; Britain's RAMCO and British Petroleum; Azerbaijan's SOCAR; Russia's LUKOIL; Norway's STATOIL; Saudi Arabia's DELTA, Japan's ITOCHU; and the Turkish Petroleum Corporation, TPAO.

39 Sasley, "Turkey Energy Politics in the Post-Cold War Era."

40 Turkish Probe, 11 April 1999.

41 S. Frederick Starr, Chairman, Central Asia Institute, Nitze School of Advanced International Studies, Johns Hopkins University, testimony before the US House of Representatives, International Relations Committee, Subcommittee on Asia and the Pacific Washington, DC, 12 February 1998; Pamir, "The Future Prospects of the Euroasian Corridor;" R.C. Longworth, "Destitute Plum of Caspian Has Many Suitors," Chicago Tribune, 9 February 1998; Turkistan Newsletter, Vol. 98:2-030, 17 February 1998; Turkistan Newsletter, Business, Vol. 98:019, 2 March 1998; Bolukbasi, "The Controversy over the Caspian Sea Mineral Resources," pp. 408-410; Sasley, "Turkey Energy Politics in the Post-Cold War Era."

42 Rob Sobhani, "Where Happiness is Multiple Pipelines," Washington Post, 8 March 1998; Stephen Sestanovich, Ambassador-at-Large, Special Advisor to the US Secretary of State for the New Independent States, statement before the US House of Representatives, International Relations Committee, Washington, DC, 30 April 1998; Ambassador Richard L. Morningstar, Special Advisor to the President and the Secretary of State, statement before the House of Representatives, International Relations Committee, Washington, DC, 30 April 1998.

43 Starr, testimony before the US House of Representatives, 12 February 1998; Pamir, "The Future Prospects of the Euroasian Corridor."

44 C. Raja Mohan, Turkistan Newsletter, "China and Geopolitics," Vol. 98:2-002, 7 January 1998; Douglas Frantz, "The Busy Bosporus is Likely to Get Even Busier," New York Times, 28 January 2001; Sobhani, "Where Happiness is Multiple Pipelines;" Stephen Sestanovich's statement, 30 April 1998; Ambassador Richard L. Morningstar's statement, 30 April 1998.

45 TDN, 17 May 1998.

46 Turkistan Newsletter, Vol. 98:2-044, 12 March 1998; Izvestia, 3 December 1997; Nezavisimaya Gazeta, 18 December 1997; Sestanovich's Statement, 30 April 1998.

47 Wihbey, “The Southern Eurasian Great Game," p. 15.

48 Sestanovich's Statement, 30 April 1998.

49 Ismail Cem, interview, TDN, 31 July 2000.

50 Valery Chaldize, "Some Routes Are More Alternative than Others', Turkistan Newsletter, Vol. 98:2-065, 9 April 1998.

51 Sabah, 11 May 2000.

52 Ismail Cem, interview, TDN, 31 July 2000.

53 Federico Pena, testimony before the US House of Representatives, 30 April 1998.

54 Sabah, 11 May 2000; Robert W. Gee, testimony before the US House of Representatives, International Relations Committee, Subcommittee on Asia and the Pacific, Washington, DC. 12 February 1998.

55 Sobhani, "Where Happiness is Multiple Pipelines;" Wihbey, "The Southern Eurasian Great Game," p. 13.

56 Wihbey, “The Southern Eurasian Great Game," p. 15.

57 Thomas Friedman, Ha'aretz, reprinted from the New York Times, 28 August 1996.

58 Starr, testimony before the US House of Representatives, 12 February 1998; Gee, Testimony before the US House of Representatives, 12 February 1998. 
59 On the United States dual containment policies see Ha'aretz, 28 June 2001; Bill Sellars, "Playing with Fire," Arabies Trends, No. 38, January 2001, pp. 18-21; William Hale, "Economic Issues in Turkish Foreign Policy," in Alan Makovsky and Sabri Sayari (eds), Turkey's New World: Changing Dynamics in Turkish Foreign Policy, Washington, DC, Washington Institute for Near East Policy, 2000, p. 35; Michael Eisenstadt, "U.S. Military Capabilities in the Post-Cold War: Implications for Middle East Allies," MERIA Journal, Vol. 2, No. 2, Eisenstadt: US Military and ME, 10 December 1998; Lawrence Kaplan, New Republic, Vol. 223, No. 18, 30 October 2000, pp. 28-30; Zvi Barel, Ha'aretz, 8 November 2000; Ha'aretz, 14 December 2000.

60 Agence France Presse, 8 January 1998; Cumhuriyet, 18 December 1997; George S. Harris, "U.S.-Turkish Relations," in Alan Makovsky and Sabri Sayari (eds), Turkey's New World: Changing Dynamics in Turkish Foreign Policy, Washington, DC, Washington Institute for Near East Policy, 2000, p. 190.

61 Stephen Kinzer, "Turks and Americans Assess Hopes and Realities of Diplomatic Ties," New York Times, 9 March 1998; Meeting of the Turkish-American Council, Washington, DC, 27 February 1998.

62 TDN, 15 December 1997. See also Kamorun Inan, Turkish Secretary of State for Energy in the 1980s, Yeni Safak, 2 December 1996; Thomas Friedman, New York Times, reprinted in Ha'aretz, 28 August 1996.

63 Wihbey, "The Southern Eurasian Great Game," p. 15.

64 Alon Liel, Turkey, Islam and Politics, 1970-2000, Tel Aviv, Hakibbutz Hameuchad, 1999, p. 120 (Hebrew); Ha'aretz, 28 October 1991; TDN, reprinted in Ha'aretz, 19 September 1996.

65 Liel, Turkey, Islam and Politics, 1970-2000, p. 120; Ha'aretz, 28 October 1991; TDN, reprinted in Ha'aretz, 19 September 1996.

66 Tamar Gabelnick, William D. Hartung and Jennifer Washburn, Arming Repression: U.S. Arms Sales to Turkey during the Clinton Administration, The World Policy Institute and the Federation of American Scientists, October 1999, available at www.fas.org/asmp/ library/reports/turkeyrep.htm\#assis.

67 Kemal Kirisci, "Turkey and the United States: Ambivalent Allies," paper presented in a conference on "America's Allies in a Changing World," 9-10 November 1998, the BESA Center for Strategic Studies, Bar-Ilan University, Israel; Andrew Mango, "Reflections on the Ataturkist Origins of Turkish Foreign Policy and Domestic Linkages," in Alan Makosky and Sabri Sayari (eds), Turkey's New World: Changing Dynamics in Turkish Foreign Policy, Washington, DC, Washington Institute for Near East Policy, 2000, p. 15.

68 Turkish Prime Ministry, Undersecretariat of Foreign Trade, TDN, 10 July 1999.

69 Sabah, 17 April 2000; Marc Grossman, Assistant Secretary of State for European Affairs, "Why Turkey Matters," Philadelphia, The Middle East Forum, 13 March 2000; TDN, 15 December 1997.

70 Turkish Probe, 30 November 1997.

71 Ibid.; Kemal Kirisci, "Turkey and the United States"; Ugur Akinci, "Enhancing Partnership is a Two-Way Street," TDN, 15 December 1997.

72 Kirisci, "Turkey and the United States;" Ugur Akinci, "Enhancing Partnership is a TwoWay Street," TDN, 15 December 1997.

73 Yediot Ahronot (Hebrew), 21 June 1998; Harris, “U.S.-Turkish Relations,” p. 195.

74 David B. Ottaway, International Herald Tribune, 14 December 1998.

75 The Financial Times wrote that Iran, in concluding these deals, had "scored a foreign policy coup," Financial Times, 30 December 1997.

76 Bill Sellars, "Playing With Fire"; Hale, "Economic Issues in Turkish Foreign Policy," p. 35.

77 Ilnur Cevik, editorial, TDN, 26 May 1999.

78 Kirisci, "Turkey and the United States." 
79 Ibid. (italics added); Oguz Celikkol, Turkish Under Secretary of State for Middle Eastern Affirs, Lecture, Ankara, The Middle East Technical University, 12 May 1999.

80 Ilnur Cevik, editorial, TDN, 26 May 1999.

81 Mark Parris, former US Ambassador to Turkey, lecture, the Washington Institute, 17 April 2001, Policywatch, No. 530, 19 April 2001. See also Amin Tarzi, "Contradictions in U.S. Policy on Iraq and its Consequences," MERIA Journal, Vol. 4, No. 1, March 2000; Harris, "U.S.-Turkish Relations," pp. 193-194.

82 TDN, 10 February 1999; TDN, 28 April 1999; Ha'aretz, 17 October 2000; Harris, “U.S.-Turkish Relations," p. 198.

83 Ibid., pp. 193-194; TDN, 27 February 1999.

84 Time, "Death Is the Only Solution," 25 February 2002; Der Standard (Austrian), 14 May 1996; Daily News Bulletin (Greek), 15 May 1996.

85 Time, 25 February 2002.

86 TDN, 1 March 1999; 5 May 1999; 9 May 1999.

87 Der Standard (Austrian), 14 May 1996; Daily News Bulletin(Greek), 15 May 1996.

88 Turkish Probe, 9 May 1999; TDN, 13 February 1999; Harold Pinter, Guardian, reprinted in Ha'artez, 25 February 1999; Time, 25 February 2002.

89 Harold Hongju Koh, US Assistant Secretary of State for Democracy, interview, TDN, 6 August 1999; Gabelnick, Hartung, and Washburn, Arming Repression.

90 TDN, 1 March 1999; TDN, 5 and 9 May 1999.

91 Der Standard (Austrian), 14 May 1996; Daily News Bulletin(Greek), 15 May 1996.

92 Harold Hongju Koh, U.S. Assistant Secretary of State for Democracy, interview, TDN, 6 August 1999; Gabelnick, Hartung, and Washburn, Arming Repression. In July 1999, the Turkish parliament extended the state of emergency in the southeast's six provinces, marking over twelve years of emergency rule in the region.

93 Reprinted in Stephen Kinzer, "Mayor Guilty of Godliness: What Next for Turkey?" MERIA Seminar, 7 October 1998.

94 Daily News Bulletin, 19 March 1997; Stephen Kinzer, New York Times, 20 March 1998.

95 Harold Hongju Koh, U.S. Assistant Secretary of State for Democracy, interview, TDN, 6 August 1999; Gabelnick, Hartung, and Washburn, Arming Repression.

96 Kirisci, "Turkey and the United States."

97 Gabelnick, Hartung, and Washburn, Arming Repression.

98 Meeting of the Turkish-American Council, Washington, DC, 27 February 1998; Kirisci, "Turkey and the United States."

99 Gabelnick, Hartung, and Washburn, Arming Repression.

100 For more on Turkish-Israeli relations see Chapter 7.

101 Reginald Dale, "EU Needs to Make-Up with Turkey," International Herald Tribune, 5 May 1998. While in Berlin, to mark the fiftieth anniversary of the Berlin airlift, President Clinton called for Turkey's membership in the EU, to the "annoyance and opposition" of his host, Chancellor Kohl. Andrew Gimson, "Clinton Backs Turkey's Fight to Join the EU," Daily Telegraph, 14 May 1998; Kenneth B. Moss, "Europe, the Mediterranean, and the Middle East," MERIA Journal, Vol. 4, No. 1, March 2000.

102 Nigel Rodney, former director of Amnesty International and a UN expert on instances of torture and ill treatment throughout the world, reported that "torture in Turkey has decreased 'notably' over the last two years." He rather cynically attributed this to the shorter detention periods, which meant that there was simply less time available to torture prisoners. See TDN, 9 April 1999; Gabelnick, Hartung, and Washburn, Arming Repression.

103 TDN, 27 February 1999.

104 See Stephen Kinzer, “The Last Supper of Press Freedom," New York Times, reprinted in Ha'aretz, 19 June 1998. 